\title{
Human Rights Prosecutions and Autocratic Survival
}

\author{
Abel Escribà-Folch \\ Universitat Pompeu Fabra \\ Joseph Wright* \\ Pennsylvania State University
}

October 9, 2013

\begin{abstract}
Do human rights prosecutions deter dictatorships from relinquishing power? Advances in the study of human rights show that prosecutions reduce repression in transition countries. However, prosecuting officials for past crimes may jeopardize the prospects of regime change in countries that have not transitioned, namely dictatorships. The creation of the International Criminal Court has further revitalized this debate. This paper assesses how human rights prosecutions influence autocratic regime change in neighboring dictatorships. We argue that when a dictator and his elite supporters can preserve their interests after a regime transition, human rights prosecutions are less likely to deter them from leaving power. Using personalist dictatorship as a proxy for weak institutional guarantees of post-transition power, the evidence indicates that these regimes are less likely to democratize when their neighbors prosecute human rights abusers. In other dictatorships, however, neighbor prosecutions do not deter regimes from democratizing.
\end{abstract}

${ }^{*}$ The authors thank two reviewers, the editor, Xun Cao, Jeff Colgan, Courtenay Conrad, Sarah Croco, Yoshi Kobayashi, James Morrow, Jessica Weeks, and participants at the Rice University Workshop on "The International Politics of Autocracies" (May 2012) and an EPSA (June 2012) panel for excellent feedback and helpful conversations. We thank Drew Linzer and Jeffrey Staton for sharing their data on judicial independence. This research is supported by NSF-BCS \#0904478. Emails: abel.escriba@upf.edu and josephgwright@gmail.com (corresponding author). 
The trials of deposed dictators such as Hosni Mubarak and Slobodan Milosevic, as well as the indictments of sitting heads of state Omar Hassan al-Bashir and Muammar Gaddafi, have brought renewed attention to the debate about the consequences of prosecuting autocratic elites. ${ }^{1}$ Do such prosecutions prevent other dictators from leaving power?

Given the paucity of ICC indictments to date, much less successful prosecution, there is little room to assess how ICC actions influence the behavior of repressive dictatorships. However, Figure 1 shows that the number of human rights prosecutions has risen quickly in the past 30 years. $^{2}$ There was just one prosecution in 1979 , but the number rises to more than ten per year in the 2000s. ${ }^{3}$ Overall, the majority of prosecutions are domestic, such as the cases brought against Hosni Mubarak in Egypt and Hastings Banda in Malawi. But by the end of the period roughly half were international. For example, after Pinochet's arrest in the U.K. in 1998 at the behest of Judge Baltasar Garzón, Spanish courts were flooded with cases for prosecution of dictators under laws allowing for extraterritorial jurisdiction. Most were dismissed because the courts could not try sitting heads of state, but three cases against former dictators moved forward: Guatemalan General Rios Montt, Chad's former President Hissène Habré, and Désiré Bouterse of Suriname. ${ }^{4}$

The proponents of campaigns to prosecute human rights abuses hailed these events as key advancements for human rights and as signals of increased enforcement of international human rights norms. ${ }^{5}$ The optimistic view of prosecutions argues that they raise the cost of repression and thus deter regimes from abusing human rights. ${ }^{6}$

Prosecutions of dictators and the growing influence of the International Criminal Court (ICC), however, are not without critics. One set of detractors argues that prosecuting human rights abusers involved in a conflict may backfire if a political agreement is not already in place because

\footnotetext{
${ }^{1}$ The al-Bashir case marked the first time the International Criminal Court indicted a sitting head of state. Former Libyan President Muammar Gaddafi was the second.

${ }^{2}$ Kim and Sikkink 2010.

${ }^{3}$ For information on Transition Human Rights Prosecutions (THRP), see the Human Rights Prosecution Database.

${ }^{4}$ Roht-Arriaza 2005, 170.

${ }^{5}$ See, for example, Human Rights Watch 2010, Stanton 2009, and the deputy director Amnesty International's Africa program, quoted in Rice (2009).

${ }^{6}$ Kim and Sikkink 2010; Olsen, Payne and Reiter 2010.
} 


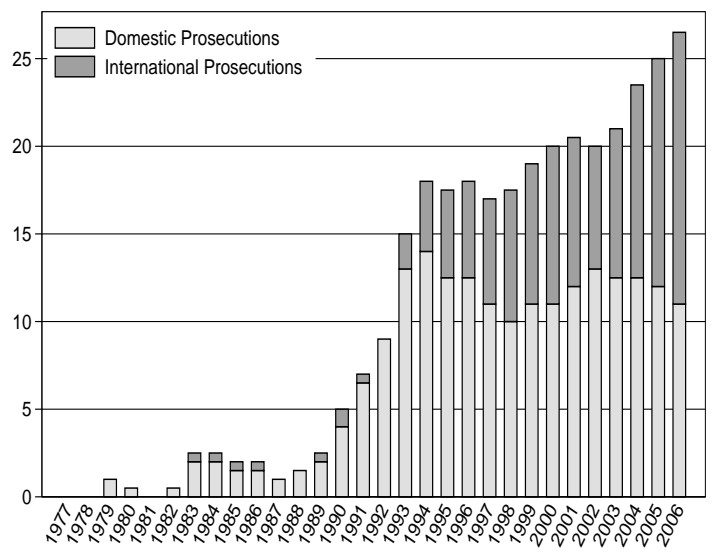

Figure 1: Transition human rights prosecutions. Global count of domestic and international prosecutions, two-year moving average. Data source: Kim and Sikkink (2010).

threatened parties have an incentive to continue fighting to avoid punishment. ${ }^{7}$ This suggests that human rights prosecutions in transition countries may hurt progress towards democratic change and in doing so worsen human rights in the long-run.

A second set of critics present a more far-reaching argument, which we test in this paper: prosecutions may deter repressive regimes from relinquishing power. ${ }^{8}$ If prosecutions deter human rights abuses in transition countries, the proximate cause is that prosecutions raise the cost of using repression. For this same reason, according to a more pessimistic view, prosecutions might also increase the cost of leaving power for autocratic regimes that have committed human rights abuses.

The toppling of dictatorships during the Arab Spring uprisings revitalized this debate. For example, in reporting on Mubarak's trial, the late Anthony Shadid noted that,

Some Arab officials even suggested that the spectacle of the trial on Wednesday - a president and his family, along with his retinue of officials, facing charges - would make [other]...leaders all the more reluctant to step down. ${ }^{9}$

${ }^{7}$ Snyder and Vinjamuri 2004. See Osiel 2000 for a review. Some argue that the ICC is ineffective because it does not have an enforcement mechanism (Goldsmith 2003), or that authoritarian regimes sign human rights treaties as a signal to the opposition of their willingness to repress (Hollyer and Rosenforff 2011). In contrast, Gilligan (2006) posits that leaders with a high probability of being deposed may be more willing to surrender to the ICC than be punished by domestic actors.

${ }^{8}$ Goldsmith 2003; Goldsmith and Krasner 2003; Sutter 1995; 2006.

${ }^{9}$ Anthony Shadid. "At Mubarak Trial, Stark Image of Humbled Power." The New York Times, 3 August 2011. 
Shadid then linked the surge of government repression against citizens in the Syrian city of Hama to the trial of Mubarak the same day, suggesting that the latter's fate may have increased the resolve of the Ba'athist dictatorship. Similarly, Phillippe Sands wrote in The Guardian that after the ICC arrest warrant, Gaddafi "was bound to dig in his heels." 10

Yet, as Sikkink and Walling point out, "there are many claims about the negative effects of trials but relatively little solid evidence to support them." ${ }^{11}$ We assess the evidence by using human rights prosecutions in neighboring countries as a proxy for expectations of post-exit punishment. This measure captures events in neighboring countries that have already experienced transitions, and thus does not rely on information from dictatorships that are currently in power. Therefore, neighbor prosecutions are more likely to be exogenous to the process of democratization than other measures - such as signing human rights treaties - which rely on information from strategic government behavior in dictatorships at risk of transition.

We argue that elites in dictatorships that have institutional mechanisms for protecting elite power after a transition are less susceptible to punishment after they step down. In military regimes, for example, officers can threaten a coup if the new democracy encroaches on their interests. In party-based dictatorships, the dominant party frequently competes in and sometimes wins elections after a transition. In personalist dictatorships, however, regime collapse and transition typically mean the old autocratic elite lose power and lack the institutional capacity to protect their interests after a transition. We build on these intuitions to argue that the evidence for the pessimistic view of human rights prosecutions should be strongest in personalist dictatorships because they typically lack a durable support party and do not have control over the military after they leave power. Using data on regime transitions from 1977-2006, we show that personalist dictatorships are less likely to democratize when more of their neighbors prosecute human rights abusers. In other dictatorships, however, we find little evidence to suggest that neighbor prosecutions deter democratic transition.

\footnotetext{
${ }^{10}$ Philippe Sands. "The ICC arrest warrants will make Colonel Gaddafi dig in his heels." The Guardian, 4 May 2011.

${ }^{11}$ Sikkink and Walling 2007, 429.
} 


\section{Transitions to Democracy and Post-exit Punishment}

Democratic transitions have been generally studied from two different approaches: ${ }^{12}$ a macro approach focusing on structural determinants of democratization, such as economic development, ${ }^{13}$ and a strategic approach focusing on interactions among actors, especially elites. ${ }^{14}$ While the structural approach may overlook the role of political actors in the process of democratization and pay too little attention to how structural features shape actors' incentives, the strategic approach has been criticized for focusing too much on elites and overlooking the role of opposition forces. However, recent contributions bridge the gap between these approaches by specifying causal mechanisms that link structural characteristics to changes in the preferences and choices of political actors. For example, economic crises,${ }^{15}$ inequality, ${ }^{16}$ access to oil and other rents,${ }^{17}$ regime institutions ${ }^{18}$ democratic diffusion, ${ }^{19}$ and membership in international organizations ${ }^{20}$ have been offered as factors which structure the incentives of individual actors to influence the prospects of democratization.

Both ex-ante destabilizing conditions and expectations about the ex-post consequences of leaving power influence transitions. The factors listed above - both domestic and external - can create destabilizing conditions by limiting the regime's capacity to buy support and thus maintain elite cohesion and by undermining its coercive capacity. Thus, destabilizing structural conditions can influence how strategic actors behave. For example, an economic crisis may decrease the rents available to buy support and spur popular dissent, thereby causing splits within the regime elite. However, the effect of destabilizing factors may vary across regime type - a structural feature. ${ }^{21}$

Given ex-ante destabilizing conditions, such as elite divisions due to economic crisis or international pressure, the ability of former elites to protect their interests in a subsequent democracy

\footnotetext{
${ }^{12}$ See Teorell 2010.

${ }^{13}$ For example, Przeworski et al. 2000.

${ }^{14}$ For example, O’Donnell and Schmitter 1986; Przeworski 1991.

${ }^{15}$ Haggard and Kaufman 1995.

${ }^{16}$ Boix 2003; Acemoglu and Robinson 2006.

${ }^{17}$ Morrison 2009.

${ }^{18}$ Geddes 1999; Wright and Escribà-Folch 2012.

${ }^{19}$ Gleditsch and Ward 2006.

${ }^{20}$ Pevehouse 2002.

${ }^{21}$ Geddes 1999.
} 
influences their willingness to negotiate a transition and relinquish power. Despite receiving theoretical attention, this claim has not been systematically tested yet. The strategic approach emphasizes that outgoing elites want to avoid punishment after leaving power, with exit guarantees making peaceful transitions more likely. ${ }^{22}$ This paper contributes to the democratization literature by explaining and empirically testing how expectations of post-exit punishment (a strategic factor) influence the prospects of democratic transitions in different autocratic contexts (a structural feature) using neighboring events as a proxy.

Figure 2 illustrates how ex-post expectations of punishment can influence transitions in a twoplayer game. ${ }^{23}$ Assuming the regime faces challengers motivated by some proximate destabilizing event - such as a mass protest, uprising, or elite divisions - which may lead to a particularly bad outcome for regime elites, they choose between retaining power and negotiating exit as part of a democratic transition. Should they choose the latter, the new democratic government decides whether to honor the agreement or to renege and punish them.

The opposition prefers regime change, and after transition, to punish former autocratic elites for past crimes or corruption: DP > DI > SQ. ${ }^{24}$ Given these preferences, even if the regime prefers democracy with immunity to the status quo, a peaceful transition is not possible when the regime prefers the status quo to democracy with punishment. There is only one Nash-equilibrium, the status quo (SQ), with the dictatorship fighting to stay in power. Anticipating that the opposition has an incentive to renege on the transition pact, the regime does not transfer power peacefully since holding onto power is the best protection against punishment. Transition is only possible if the regime is forcibly removed from power. ${ }^{25}$ Hence, negotiated promises that grant immunity

\footnotetext{
${ }^{22}$ Dix 1982; O’Donnell and Schmitter 1986; Huntington 1991; Przeworski 1991. Similarly, recent formal theories of democratization focus on the economic (not personal) consequences of democratization to argue that elites are less threatened by democratization in countries with relatively low inequality Boix 2003; Acemoglu and Robinson 2006.

${ }^{23}$ Sutter 1995; Nalepa 2010.

${ }^{24} \mathrm{DP}$ denotes democracy and punishment; DI democracy and immunity; and SQ status quo. The symbols represent the utility payoffs of each scenario.

${ }^{25} \mathrm{An}$ alternative is the dictator fleeing to exile. To alleviate the punishment dilemma, the outgoing ruler may be granted asylum in a foreign country (Sutter 1995). As the risk of regime collapse increases, the utility of fleeing may surpass that of fighting to retain power. Indeed, going into exile has eased regime transitions in some countries and has been a common fate for many dictators,
} 


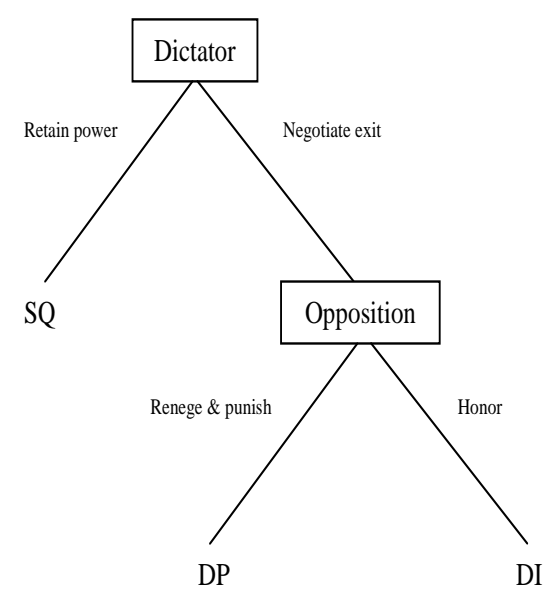

Figure 2: The commitment problem in a transition game.

to former elites face a commitment problem, which stems from the fact that after ceding power through a pact the democratic government cannot credibly enforce such promises. ${ }^{26}$

In short, factors that increase the expectation that regime elites will be punished after a transition or will be unable to find asylum in a foreign country should lower the chances that the regime negotiates exit, making a peaceful transition less likely. ${ }^{27}$ Whether prosecution of human rights abusers in neighboring countries (our proxy of ex-post expectations of punishment) deters democracy will therefore hinge on whether these prosecutions increase the expectation of ex-post punishment.

This logic informs one of two competing views of human rights prosecutions, each of which points to different policy prescriptions for addressing past human rights abuses. ${ }^{28}$ The pessimistic view argues that strategic considerations about the likelihood of punishment after leaving power deter leaders from stepping down. Alternatively, an optimistic view, which focuses on transition countries, claims that prosecutions deter repression by making such behavior more costly to the perpetrators.

such as Tunisia's Ben Ali, Philippines' Ferdinand Marcos, and Haiti's Jean-Claude Duvalier. ${ }^{26}$ Sutter 1995.

${ }^{27} \mathrm{~A}$ new democracy is less likely to emerge after autocratic regime collapse if the such collapse event is violent: roughly two-thirds of democratic transitions are the result of peaceful regime collapse events (Geddes, Wright, and Frantz 2014).

${ }^{28}$ Olsen, Payne and Reiter 2010. 


\section{The Pessimistic View}

The early comparative literature on democratic transitions identified prosecutions for past abuses as a potential obstacle to democratization. Thus, Dix emphasizes that 'exit guarantees' for former ruling elites increase the chances of successful transition, while O'Donnell and Schmitter argue that past repression under military rule hinders pacted transitions to democracy. ${ }^{29}$ Further, if the military remains strong and cohesive, a democracy with some guarantees of the military's interests - including immunity from prosecution - can facilitate extrication of the autocratic regime. ${ }^{30}$ Consistent with the main prediction of the game in Figure 2, these theories suggest that the anticipation of punishment associated with transition reduces the likelihood that authoritarian elites relinquish power through a negotiated process. ${ }^{31}$ Similarly, in his 'guidelines for democratizers', Huntington notes that new democratic authorities should not prosecute former officials for human rights violations. ${ }^{32}$

Concern that prosecutions will deter repressive leaders from leaving power also informs critics of the International Criminal Court (ICC). Some argue that the growing reach of the ICC will prompt dictators to hold onto power. ${ }^{33}$ For example, the ICC may take "away states' ability to commit to non-prosecution in the case of amnesties." 34 Recent indictments of sitting rulers, such as al-Bashir and Gaddafi, have further fueled this debate because these actions targeted individuals who were concurrently facing pressure to step down peacefully. In short, the pessimistic view emphasizes that unless some mechanism exists to credibly prevent new elites from punishing former authoritarian elites, a peaceful, negotiated democratic transition is unlikely.

However, elites in some dictatorships, particularly those with an organizational basis, possess

${ }^{29}$ Dix 1982; O’Donnell and Schmitter 1986.

${ }^{30}$ Przeworski 1991.

${ }^{31}$ Sutter 1995.

${ }^{32}$ Huntington 1991. This reasoning informed the decision to pass amnesty laws during transitions in countries such as Argentina, Uruguay, and Spain. More recently, the Gulf Cooperation Council (GCC) initiative for Yemen, presented in April 2011, stated that Saleh would resign and transfer power in return for immunity from prosecution.

${ }^{33}$ Goldsmith 2003; Goldsmith and Krasner 2003; Snyder and Vinjamuri 2004; Nalepa and Powell 2011.

${ }^{34}$ Ginsburg 2009, 499. 
institutionalized mechanisms for retaining some power even after democratization. The extent to which autocratic elites expect their power to be protected after transition, in turn, shapes their beliefs about the likelihood of post-transition punishment. Therefore, in dictatorships where elites can expect to retain some post-transition power, the pessimistic logic should be weaker. And, as Huntington argues, the ability to protect post-tranisition power varies by autocratic regime type:

The party gives up its monopoly of power but not the opportunity to compete for power by democratic means. When they return to the barracks, the military give up both, but they also retain the capacity to reacquire power by nondemocratic means. ${ }^{35}$

Military regimes are dictatorships where the military as an institution rules and thus constrains the power of the nominal leader. These contrast with personalist dictatorships where, even though the leader may wear a military uniform and has come to power in a coup, the military and highranking officers have been subordinated to the power of the leader. ${ }^{36}$ For military regimes, the capacity to make credible transition pacts stems from their advantage in violence. Exit guarantees are credible because the military retains the capacity to reintervene in politics if the new political elites encroach upon their interests. In Argentina, the prosecution of former junta leaders prompted military unrest and a coup threat, forcing Alfonsín's government to pass immunity laws shortly after the transition. ${ }^{37}$ Similarly, during Brazil's transition, the military eliminated "most of the proposed constitutional clauses that would have curtailed military autonomy." 38 The military's willingness to bargain indicates they may have longer-lasting power and are thus more likely than other autocratic elites to return power to civilians through a pacted transition. ${ }^{39}$ The game in Figure 2 illustrates this logic. If the opposition opts to renege and initiate prosecutions, the military can decide whether to reintervene to stage a coup. This threat, if credible, is sufficient to induce the opposition to refrain from revising the past. Indeed, many argue that a central reason militaries intervene in politics is to protect their corporate interests, of which a primary one is immunity from prosecution. ${ }^{40}$

\footnotetext{
${ }^{35}$ Huntington 1991, 120.

${ }^{36}$ Nordlinger 1977; Geddes 1999; Weeks 2008.

${ }^{37}$ Nobles 2010.

${ }^{38} \mathrm{Linz}$ and Stepan 1996, 169.

${ }^{39}$ Sutter 1995.

${ }^{40}$ Stepan 1971; Thompson 1975; Nordlinger 1977.
} 
Dominant-party dictatorships also frequently end in negotiated transitions, with the regime party competing in post-transition elections. ${ }^{41}$ Thus the dominant party can act as a veto player after a democratic transition, much like the military does in many new democracies that follow military regimes. Dominant-party autocracies typically have cohesive cadres and relatively broad support coalitions, with an institutional struture that produces power-sharing agreements, credible policy concessions, and opportunities to respond to the demands of diverse social groups. ${ }^{42}$ They also buy mass support through broad patronage networks, distributing benefits and public employment by politicizing public resources. ${ }^{43}$ Such features allow party elites to mobilize support and increase their power vis-à-vis the opposition during bargaining over electoral rules of the new democracy. Indeed, former dominant regime parties have generally won at least the second largest share of seats in the legislature in post-transition democracies, with some former dominant parties even retaking legislative majorities or the executive. ${ }^{44}$ Consequently, these elites are likely to retain post-transition political leverage.

In terms of the logic depicted in Figure 2, if elites from a former party regime win some legislative power, they can block a new democratic government's policy choices that lead to punishment. Because of the control of new institutions by the regime party or the pressence of former regime elites among the constituent members of the new regime, the regime's preferences would no longer be $\mathrm{DP}>\mathrm{DI}>\mathrm{SQ}$, but $\mathrm{DI}>\mathrm{DP}>\mathrm{SQ} \cdot{ }^{45}$ An example from post-Communist transitions in Eastern Europe illustrates this point. David compares the timing and scope of lustration laws after transitions in Poland and Czechoslovakia to show that these laws in Poland were more limited and passed more than a decade after the transition because of the negotiated nature of the transition. ${ }^{46}$ This allowed some former communists to retain power. The first Polish elections in 1989 were only

\footnotetext{
${ }^{41}$ Huntington 1991; Ishiyama 1995; Geddes 1999.

${ }^{42}$ Geddes 1999; Smith 2005; Magaloni 2008.

${ }^{43}$ Magaloni 2006; Greene 2010.

${ }^{44}$ Wright and Escribà-Folch 2012.

${ }^{45}$ Further, Nalepa argues that after the breakdown of party regimes in Communist Europe, transitional justice was avoided because notable opposition members had worked as informants for the authoritarian police. Elites in the new democracy therefore did not renege on their promise of amnesty in an effort to avoid exposing their own 'skeletons in the closet.' See Nalepa 2010.

${ }^{46}$ David 2003.
} 
partly competitive with just one-third of parliamentary seats contested, and Jaruzelski remained President until 1990. The Democratic Left Alliance (SLD), controlled by former communists and opposed to lustration, collected the second largest vote total in the 1991 legislative election, and won the 1993 parliamentary and the 1995 presidential election. This prevented the creation of a legislative majority necessary to pass a lustration law until the victory of the center-right in 1997.

Personalist dictatorships stand apart from regimes based on an institutionalized organization such as a party or the military. Leaders in these autocracies often rely on relatively small support coalitions whose loyalty is ensured by the distribution of material rewards. ${ }^{47}$ The leader typically has near-complete control over decision-making and political appointments. ${ }^{48}$ Further, personal rulers tend to weaken the two institutions, the party and the military, that are most capable of defending their interests after they leave power, which reinforces the logic of the model in Figure 2.

Personalist dictators often undermine the collective action capacity of their militaries to reduce the risk of coups. ${ }^{49}$ An array of coup-proofing strategies - such as controlling internal promotion and recruitment, using ethnic or familial criteria for officer selection, purging officers and units, and creating parallel security organizations - ensure loyalty but do so at the expense of weakening the institutional structure of the armed forces. By patrimonializing the military, these leaders rarely have allies within the military once they leave power because losing power means their key supporters in the military have lost power as well.

Likewise, while legislatures and parties typically help enforce power-sharing agreements and policy concessions,${ }^{50}$ the logic of patrimonialism renders these institutions as mere instruments of patronage in personalist regimes. ${ }^{51}$ Appointments provide access to rents and other benefits, but those selected are subject to frequent rotation to prevent the creation of independent power bases. Parties in these regimes are frequently the creation of the leader and often do not survive him. The support parties in Mobutu's (MPR) and Trujillo's (PD) regimes, for example, disintegrated once they lost power. Gaddafi did not have a support party and, relying heavily on mercenaries, left no

\footnotetext{
${ }^{47}$ Snyder 1992; Bratton and van de Walle 1994; Chehabi and Linz 1998.

${ }^{48}$ Geddes 1999; Frantz and Ezrow 2011.

${ }^{49}$ Quinlivan 1999.

${ }^{50}$ Gandhi 2008; Magaloni 2008; Boix and Svolik 2013.

${ }^{51}$ Lust-Okar 2005; Wright 2008.
} 
All regime transitions

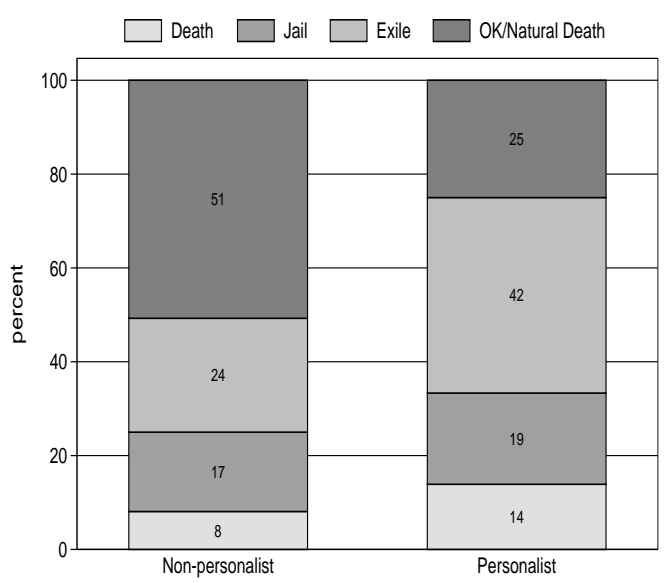

Democratic transitions

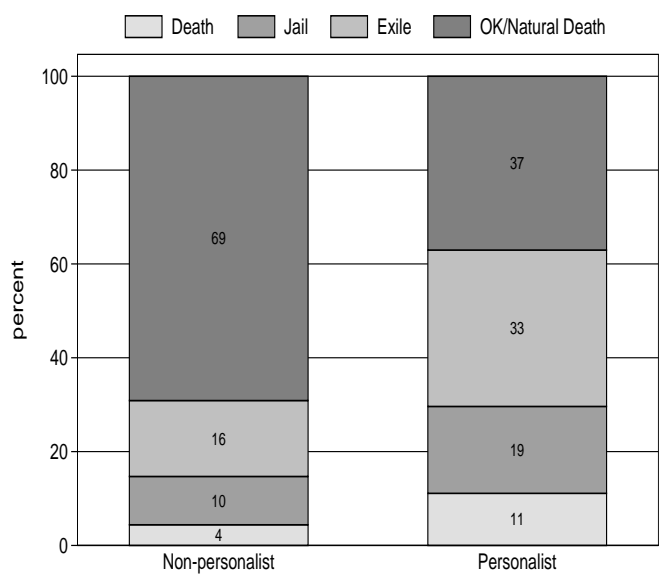

Figure 3: The fate of dictators after regime transition. Bars depict the baseline propensity for different leader post-exit outcomes. Leaders are those who hold power on January 1 of the calendar year in which the regime failure occurs. Data sources: Goemans, Gleditsch and Chiozza 2009 and Geddes, Wright and Frantz 2014. Years: 1946-2004.

military structure behind when his regime fell.

With alienated militaries and weak parties, personalist rulers have less capacity to threaten new elites or to retain leverage. Therefore, they are less likely to have institutional guarantees to protect their interests if they leave power after negotiations. For such rulers, retaining power may be the best protection against punishment. Figure 3 illustrates this point by showing the baseline probability of different post-exit outcomes for autocratic leaders who are in power when a regime transition occurs. The left panel shows the fate of these dictators after all regime transitions. Indeed, personalist dictators have faced a worse fate when their regime is ousted: three-quarters end up with a 'bad' fate such as exile, jail or death. In contrast, over one-half of non-personalist dictators are 'okay' or die naturally. ${ }^{52}$ The right panel shows the same baseline probabilities but restricts the sample to leaders whose regime ousters end in a democratic transition. While the fate of dictators is generally better after democratic transitions, the same differences between personalist and non-personalist leaders persist.

Hence, the logic of the pessimistic view should be strongest in personalist dictatorships because they have the fewest domestic institutional guarantees of their interests after a transition and

\footnotetext{
${ }^{52}$ For further evidence see: Escribà-Folch 2013.
} 
should therefore be the most sensitive to changes in externally-generated costs of leaving power. This conditional pessimistic hypothesis suggests that neighboring-country prosecutions for human rights abuses are more likely to deter democratic transition in personalist dictatorships.

\section{The Optimistic Approach}

Advocates of prosecutions argue that by improving accountability, establishing rule of law, and raising the cost of repression, punishment can deter future abuses. ${ }^{53}$ The increasing domestic legalization of human rights regimes and the recent growth of international agreements obliging states to address human rights abuses have accompanied a steady rise in prosecutions. ${ }^{54}$ The potential costs associated with punishment are not only material (freedom and income), but also social. ${ }^{55}$ Aware of the increased probability of prosecution, proponents argue, state officials should refrain from violating human rights. Indeed, the threat of prosecutions may deter human rights abuses even in the absence of reliable enforcement mechanisms. ${ }^{56}$

Recent evidence that human rights prosecutions in transition countries reduce state repression supports the optimistic view. ${ }^{57}$ Further, deterrence may extend to neighboring countries: transitional states reduce repression when their neighbors prosecute past abusers. Evidence from Latin American cases suggests that human rights trials improved respect for human rights and democratic accountability ${ }^{58}$ while others show that trials combined with other forms of transitional justice can have positive effects on democraticness and human rights. ${ }^{59}$

The optimisitic view focuses on how prosecutions influence repression in countries that have already transitioned from autocracy, not immediate decisions about whether to negotiate an exit from power. However, if prosecutions make the use of repression more costly in the future, this mechanism may also influence the prospects for political survival. First, public knowledge of costly repression can signal to the opposition that the regime is less capable of suppressing dissent and thus

\footnotetext{
${ }^{53}$ Olsen, Payne and Reiter 2010.

${ }^{54}$ Méndez 1997; Lutz and Sikkink 2001; Sikkink and Walling 2007; Kim and Sikkink 2010.

${ }^{55}$ Kim and Sikkink 2010.

${ }^{56}$ Ritter and Wolford 2012.

${ }^{57}$ Kim and Sikkink 2010; Olsen, Payne and Reiter 2010.

${ }^{58}$ Sikkink and Walling 2007.

${ }^{59}$ Olsen, Payne and Reiter 2010.
} 
spur anti-regime mobilization. Second, prosecutions may increase the likelihood that the repressive apparatus refuses to use violence against regime dissenters. Thus the likelihood that a dictator can successfully defend against violent threats to his rule when they arise - which increases the prospect that he ends up killed or jailed - decreases.

In terms of the logic in Figure 2, if prosecutions raise the long-term cost of repression for the regime, then when a dictator chooses to hold onto power (SQ) there is some probability, $p$, that he successfully fights for survival and retains power. Yet, with probability 1-p the leader is coercively ousted and faces a higher risk of a nasty fate. If, by emboldening the opposition or reducing security forces' willingness to repress, human rights prosecutions decrease $p$, the expected utility of staying in power decreases as well. Autocratic elites may thus face an intertemporal dilemma. On the one hand, they can decide to stay in office, but at the risk of being less capable of handling dissent in the future. Alternatively, they may opt to step down in the current period provided they are able to negotiate with opposition forces and ensure a relatively benign fate after democratic transition. Prosecutions may therefore increase the likelihood that regime elites negotiate a peaceful exit from power. Again, this prediction should vary with regime type.

Leaders in personalist dictatorships have more control over the selection of high-level military and security officers, and are more likely to personally command these organizations. ${ }^{60}$ Control over the military and the creation of parallel security forces allow the dictator to staff these organizations using familial, ethnic, or sectarian loyalties, making them more dependent on a specific autocratic ruler remaining in office. ${ }^{61}$ Such strategies strengthen the loyalty of these groups, reduce the likelihood of defections, and facilitate the regime's repressive response to challengers.

Alternatively, in non-personalist regimes military and security forces are often less patrimonialized and more highly institutionalized. These organizations tend to be "rule-governed, predictable, and meritocratic," with "established paths of career advancement and recruitment." 62 Thus the leaders of the coercive apparatus in these dictatorships are less likely to be tied to the regime leader and more likely to survive in their position should the regime fall. In Chile, for example, the

\footnotetext{
${ }^{60}$ Geddes 1999; Weeks 2012.

${ }^{61}$ Quinlivan 1999.

${ }^{62}$ Bellin 2004, 145.
} 
leader of the military junta that democratized in 1989 not only retained his status as a general but continued for nearly a decade as the head of the armed forces.

When faced with anti-regime uprisings, the regime's survival often depends on whether the military and security forces use their violent capacity to repress opponents. ${ }^{63}$ "The military are the ultimate support of regimes. If they withdraw their support, (...) the regime falls."64 And as Bellin notes, institutionalization "determines the degree to which the military elite is personally invested in the regime's survival." ${ }^{65}$ Officers in an institutionalized military are more likely to turn their backs on the regime because they typically have fewer ties to the ruler and a more developed 'corporate identity' linked to defending the state rather than the regime. If prosecutions in neighboring countries provide a signal that repression is more likely to be punished, the interests of the military may be better served by defecting rather than by fighting for regime survival.

Recent events during the Arab Spring uprisings illustrate this point. In Tunisia, General Ammar, the army chief of staff, refused to obey Ben-Ali's order to shoot protesters and the dictator soon fled to exile. The Tunisian military was not highly personalized under Ben-Ali and "in time came to rank among the Arab world's most professional forces." ${ }^{66}$ In Egypt, the decision to defect took more time, with the military initially helping other security forces. However, after violence intensified, the army announced its refusal to use force and the Supreme Council of the Armed Forces quickly forced Mubarak to resign. Egypt's military is highly institutionalized and their institutional economic interests conflicted with Mubarak's plan to elevate his son to succeed him. ${ }^{67}$ These cases contrast with Libya and Yemen, where the dictators' sons held key posts in the regimes' most repressive military divisions.

If growing international protection of human rights and increasing resolve to prosecute violators make future repression more costly, elites in non-personalist regimes may have an incentive to step down in a controlled transition provided that they have institutionalized exit guarantees to make transition agreements credible. Regime change may thus be preferable to the uncertainty of fighting

\footnotetext{
${ }^{63}$ Bellin 2004; Stephan and Chenoweth 2008; Svolik 2011.

${ }^{64}$ Huntington 1991, 144-145.

${ }^{65}$ Bellin 2012, 132.

${ }^{66}$ Barany 2011, 31.

${ }^{67}$ Bellin 2012.
} 
for regime survival. Hence, this conditional optimistic hypothesis suggests that neighboring-country prosecutions for human rights abuses are less likely to deter democratic transition in non-personalist dictatorships.

\section{Changing Punishment Expectations and Measurement}

Both the pesimistic and optimistic views hinge on elites' estimates of the likelihood of being punished after a transition. It is difficult, however, to test this logic because these expectations are not directly observable. Further, while recent evidence suggests that prosecutions reduce repression, ${ }^{68}$ these studies focus on countries that have already transitioned to democracy and therefore cannot rule out the possibility that unobserved factors in the new democracy cause both the timing of prosecutions after transition and improvements in human rights. The decision to prosecute may be endogenous to the political strength of the repressive actors. ${ }^{69}$ Thus if countries only prosecute former abusers when the latter are less threatening, we only observe the benefits of prosecutions.

To address these issues, we measure the dictator's perception of the likelihood of post-transition punishment with a proxy: the number of human rights prosecutions in neighboring countries that have already transitioned. This approach assumes that dictators observe prosecutions in proximate countries and expect that the politics of human rights punishment in their own country may be similar. ${ }^{70}$ Elites in dictatorships often use regional organizations and neighboring countries as a reference point for understanding and responding to political change. For example, Kazakhstan's prime minister, Karim Masimov, told Reuters in an interview that his government was "watching very carefully what's happening in North Africa and the Middle East." ${ }^{71}$ In another example, high-ranking generals in Pinochet's regime looked to other Southern Cone military dictatorships in Argentina and Brazil when searching for constitutional pathways to permanent rule. In response to international condemnations of human rights abuses, the generals protested that they should

\footnotetext{
${ }^{68}$ Kim and Sikkink 2010; Olsen, Payne and Reiter 2010.

${ }^{69}$ Skaar 1999; Kim 2012.

${ }^{70}$ See Haas 1992, Weyland 2005, and Meseguer 2009 for explanations of diffusion among neighoring countries.

${ }^{71}$ Robin Paxton. "Interview-Kazakh PM says opposition needed in parliament." Reuters 2 April 2011.
} 
not be subjected to the criticisms of military regimes in other parts of the world because they were "a legal government," and "not a dictatorship of the tropical variety."72

Furthermore, human rights prosecutions often result from the efforts of transnational advocacy networks that cluster geographically. ${ }^{73}$ These transnational networks, in turn, use news media, which may reflect a regional bias in reporting on human rights abuses. ${ }^{74}$ Autocratic elites are therefore likely to be more aware of and influenced by regional changes in human rights regimes. These elements suggest a regional element to the relevant reference group for autocratic elites, with implications for human rights politics and democratic transitions. ${ }^{75}$

Although the structure of the regime - in our case whether it is personalist - can influence the likelihood of post-exit punishment, regime type also measures other institutional characteristics such as their vulnerability to internal splits - that also strongly influence transitions. ${ }^{76}$ Neighbor prosecutions, on the other hand, directly capture post-exit expectations that vary over time and space. We expect the influence of neighboring prosecutions on the prosepcts of democratic transition to be higher in personalist regimes, for two reasons.

First, regime opponents pay attention to events in neighboring countries. For example, news reports indicate that hours after Gaddafi's death at the hands of rebels, anti-regime protesters in Syria filled to streets chanting slogans urging a similar fate for Asad. ${ }^{77}$ Gaddafi's death also prompted reactions from Iranian anti-regime bloggers, with one writing "Gaddafi was killed, be scared dictator," and another stressing "I hope Khamenei has seen Gaddafi's photos." 78 Prosecutions in neighbor countries may increase the opposition willingness and capacity to prosecute because human rights prosecutions are influenced by diffusion processes in geographic and cultural

${ }^{72}$ Hawkins 2002, 64.

${ }^{73}$ Keck and Sikkink 1998; Lutz and Sikkink 2001; Hafner-Burton and Ron 2009.

${ }^{74}$ Hafner-Burton and Ron 2013.

${ }^{75}$ Brinks and Coppedge 2006; Hafner-Burton and Ron 2009.

${ }^{76}$ For example, despite having mechanisms to protect their interests after a transition, party regimes are the most durable while military regimes are the most fragile. Geddes 1999; Brownlee 2007; Magaloni 2008.

${ }^{77}$ Richard Spencer. "Syrian protesters killed as they demonstrate in honour of Gaddafi's death." The Telegraph, 21 October 2011.

${ }^{78}$ See Global Voices, available at http://globalvoicesonline.org/2011/10/20/iran-be-scareddictator-gaddafi-is-dead/ [accessed 8 October 2012]. 
neighbors. ${ }^{79}$

The regulation of human rights has accelerated in the last two decades with a new model of individual criminal legal accountability emerging and diffusing during the 1980s and 1990s. ${ }^{80}$ This new model provides additional enforcement mechanisms and its adoption by states and international organizations has made possible a 'justice cascade', manifested in the rapid increase in the number of human rights prosecutions. ${ }^{81}$ As a result, domestic opposition groups may learn from other countries' experience and receive support (or pressure) from international organizations, foreign governments, and a growing number of transnational advocacy networks. While domestic opposition groups may be equally embolden to prosecute past abuses in all dictatorships, their likely success should vary by whether the outgoing elites have institutionalized protections in a posttransition setting. This translates into worse post-exit expectations for regime elites in personalist dictatorships who, we argue, are poorly equipped to withstand pressure to prosecute.

Second, our measure of punishment risk captures the practical translation of the growing international commitment and states' obligation to address past human rights abuses. ${ }^{82}$ This growing pressure not only increases the expectation that post-exit punishment is more likely for some dictators, but also reduces their options for asylum in foreign countries. Decreasing the likelihood of happy exile is particularly relevant for elites in personalist dictatorships who, because they are less capable of controlling the transition process to negotiate a credible exit, have historically been the most likely to flee their countries (see Figure 3). If exile increasingly involves the risk of punishment or is infeasible, the expected utility of this option may be lower than the utility of retaining power. Gaddafi, for example, was unable to find a suitable exile country and instead decided to fight until his death. And many deposed dictators in exile have recently faced the prospect of foreign host states either extraditing them to another country or prosecuting them. For example, the former President of Chad, Hissène Habré, will be tried for human rights abuses in a Senegalese special court despite having lived in exile in Senegal since his ouster in $1990 .{ }^{83}$ Similarly,

\footnotetext{
${ }^{79} \operatorname{Kim} 2012$.

${ }^{80}$ Sikkink 2011.

${ }^{81}$ Lutz and Sikkink 2001; Sikkink 2011.

${ }^{82}$ Sikkink 2011.

${ }^{83}$ Belgium demanded extradiction on the grounds of universal jurisdiction and the International
} 
former President of Liberia Charles Taylor initially went into exile in Nigeria in 2003, but three years later the Nigerian authorities, facing both international and domestic pressure, accepted the arrest of Taylor and his transfer to the Special Court for Sierra Leone. ${ }^{84}$ As prospects for a happy exile decreases, the influence of post-exit punishment on dictators who lack domestic institutional guarantees in a post-transition setting should strengthen. Thus, the marginal effect of neighbor prosecutions on deterring transitions should be stronger in personalist dictatorships where elites lack these guarantees.

\section{Empirical Approach}

To test these propositions, we use updated data on autocratic regimes. ${ }^{85}$ We use autocratic regimes instead of leaders because the former capture whether the group of elites who make policy and personnel decisions retains power while the latter measures whether a particular individual remains the nominal leader. In some cases, these two concepts are similar - for example in personalist dictatorships such as Gaddafi's regime in Libya. In other dictatorships, however, regular rotation of the leader is a mechanism for retaining power. For instance, in Mexico under PRI rule, presidents were limited to one six-year term. Presidents in China (post-Mao) and Iran (post-Khomeini) are also subject to limited terms. Modeling leadership survival counts these changes as equivalent to a democratic transition or ousting a regime via rebellion or uprising. Further, because many leadership changes in dictatorships constitute a reshuffle atop the regime, externally generated changes in the likelihood of post-exit punishment should not be as salient when the ruling regime remains in power. ${ }^{86}$

The autocratic regime data code whether regime collapse results in a transition to democracy Court of Justice ordered Senegal to prosecute Habré or to extradite him. Senegal and the African Union then agreed to prosecute in Senegal (Human Rights Watch 2012).

${ }^{84}$ Other ex-dictators living in exile have recently faced trials as well, including Alberto Fujimori and Jean-Claude Duvalier, and others have been tried in absentia such as Tunisia's Ben Ali and Ethiopia's Mengistu Haile Mariam.

${ }^{85}$ Geddes, Wright and Frantz 2014. The sample includes countries that are coded as dictatorships on January 1 of each observation calendar year; there are no democracies in the sample.

${ }^{86}$ Table A-3 shows that the results remain with leader survival as the dependent variable. This should not be surprising because in personalist dictatorships, leader and regime survival are roughly equivalent concepts. 
or to a new autocratic regime. ${ }^{87}$ We test the argument on democratic transitions because most of the transitions literature focuses on this type of political change. ${ }^{88}$ There are 118 autocratic regime failures in the sample (1977-2006), of which 65 are democratic transitions.

Data on transition human rights prosecutions (HRP) code international and domestic HRPs using information from U.S. Department of State Human Rights Annual Country Reports, international organizations such as the U.N. Security Council, and human rights NGOs. ${ }^{89}$ Domestic prosecutions are defined as: "those conducted in a single country for human rights abuses committed in that country", while international prosecutions refer to crimes brought to trial "in international tribunals like the ICTY and ICTR and in hybrid tribunals like in Sierra Leone," and "include foreign prosecutions like the Pinochet case." 90 This data base does not include cases from the ICC because the court's first investigation started in June 2004 but concluded in 2012, well after the temporal span of the HRP data.

While some prosecutions target low-level personnel accused of human rights violations, such as police officers or prison guards, most prosecutions target high-ranking regime officials. In Chile, the director of intelligence under Pinochet's rule was prosecuted. In Paraguay, Stroessner's police chief was targeted; in Poland a former Interior Minister; in Uruguay the Minister of Foreign Affairs; Navy commanders fell in Argentina and Ecuador; and in Romania the assassinated dictator's son stood trial. Further, many prosecutions specifically target the nominal regime leader: Hastings Banda, Juan Bordaberry, Leopoldo Galtieri, Luis García Meza, Mengitsu Haile Miriam, Manuel Noriega, Roh Tae Woo, Charles Taylor, Moussa Traoré, and Jorge Rafael Videla lead the list of dictators who faced human rights prosecutions after their regimes collapsed.

The main independent variable is a weighted count of the number of HRP's in neighboring countries in the past three years. HRP data begin in the late 1970s, so we examine a 30-year

\footnotetext{
${ }^{87}$ Duration dependence measures how long a particular autocratic regime has been in power, not the number of years since the last democracy.

${ }^{88}$ The logic of our argument should also apply to non-violent regime transitions. Examining democratic as well as non-violent transitions should increase our confidence in the findings because they measure slightly different conceptualizations of a transition where the incumbent relinquishes power. The main results hold when we examine non-violent transitions (see Table A-4).

${ }^{89}$ Kim and Sikkink 2010.

${ }^{90} \mathrm{Kim}$ and Sikkink 2010, 948.
} 
sample period from 1977 to 2006. To define neighboring countries, we calculate a weighted index using minimum distance data. ${ }^{91}$ Our measure assigns a weight equal to the inverse distance from the target $(w=1 / \ln (d))$ for neighboring countries within a $50 \mathrm{~km}$ of threshold of minimum distance. The weight decreases for each group of countries at the next distance threshold, where each threshold is an additional $50 \mathrm{~km}$ in minimum distance. This weighted measure incorporates information from all neighbors within $1000 \mathrm{~km}$ of minimum distance:

$$
w H R P_{i}=\sum_{K=1}^{20} \sum_{k \in K} w_{i K} N_{k}
$$

where $N$ is the number of HRPs in the $k$ neighboring countries within the group of countries that fall within each distance threshold $K . w=1 / \ln (d)$ is the weight assigned to the count of all HRPs $\left(N_{k}\right)$ for the countries in $K$ group. ${ }^{92}$

An initial look at the data in Figure 4 suggests that the relationship between neighor $\mathrm{Hu}-$ man Rights Prosecutions (HRPs) and democratic transition varies by the incumbent regime type. The left panel shows the difference between the mean value for lagged human rights prosecutions in democractic transition years and non-transition years. The first estimate on the left, for all dictatorships grouped together, indicates that HRPs are roughly 4.5 points higher in democratic transition years than in non-transition years. This estimate, however, obscures the fact that the difference is negative in personalist regimes $(-5.2)$ and positive in non-personalist ones (8.3).

This test does not account for other factors which may influence both transitions and human rights prosecutions. Importantly, the number of HRPs increased substantially over the past three

\footnotetext{
${ }^{91}$ Gleditsch and Ward 2006.

${ }^{92} \mathrm{~K}$ moves from 1 to 20 because we group countries that fall within each of the 20 distance thresholds between $0 \mathrm{~km}$ and $1000 \mathrm{~km}$ of minimum distance. The weight for the count of HRPs in neighboring countries within $50 \mathrm{~km}$ minimum distance is therefore $1 / \ln (50)=0.2566$. For neighboring countries that fall within $950 \mathrm{~km}$ and $1000 \mathrm{~km}$ of minimum distance, the count $\left(\sum_{k \in K} N_{k}\right)$ of neighboring HRPs is weighted by $1 / \ln (1000)=0.1448$. The sum of the weights (there are 20 weights, one for each $50 \mathrm{~km}$ distance threshold between $0 \mathrm{~km}$ and $1000 \mathrm{~km}$ ) is 3.6437 . Using an alternative weight, $w=1 / d$, does not alter the main result. Figure A-1 plots the weighted HRP variables against a similar measure using the 500km threshold in Gleditsch and Ward 2006. Figure A-4 plots the main estimate of interest using equal weighting using various distance thresholds.
} 
Unconditional

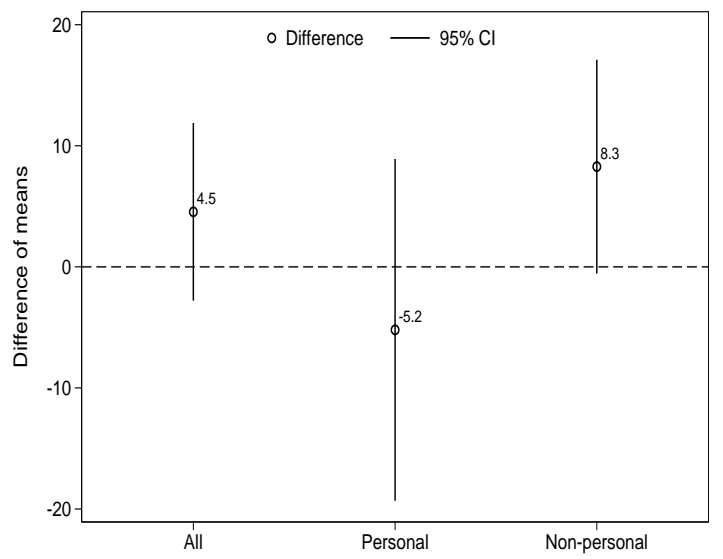

Conditional on time trend

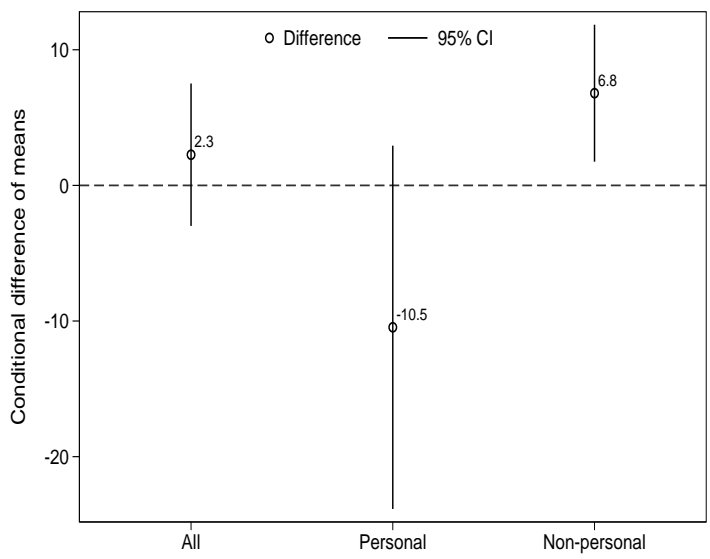

Figure 4: Human rights prosecutions, by transition year and regime type. The left panel displays the difference between the mean value for lagged human rights prosecutions in democractic transition years and non-transition years in all dictatorships, in personalist dictatorships, and in non-personalist regimes. The right panel shows the difference between the mean value for lagged human rights prosecutions in democractic transition years and non-transition years conditional on a linear time trend. Differences multiplied by 100 for ease of interpretation.

decades (see Figure 1), and this period coincides with the third wave of democratization. Therefore, we need to account for unmeasured factors that also increase over time and may be correlated with regime failure, particularly democratic diffusion. The right panel of Figure 4 shows the difference between the mean value for lagged human rights prosecutions in democractic transition years and non-transition years conditional on a linear time trend. Again, there is a large divergence in the estimates of this difference between personalist and non-personalist regimes.

Further, both the neighboring country HRP variable and the political processes that shape the prospects for democratization vary by geographic region. Figure A-2 shows that democratic transitions and neighbor HRPs are clustered geographically, which is not surprising because the prosecutions data capture political events that occur only after a country has transitioned from civil war or autocratic rule, with the majority occuring after a democratic transition. Because of this regional clustering, we cannot rely on cross-sectional variation to estimate the influence of HRPs. Finally, there may be unobserved factors which vary by country (or geographic region) - such as the strength of civil society groups, human rights norms, and the political strength of the military and other repressive actors - which are correlated both with the chances of democratization and the 
prospects of regional human rights prosecutions. For these reasons, we opt for a model specification that incorporates both country- and year- fixed effects.

We first test a set of conditional logit models. ${ }^{93}$ This approach, however, drops countries that do not transition during the sample period. For example, of the 108 countries in our sample, 54 do not have a democratic transition between 1977 and 2006. Dropping these cases substantially increases the baseline probability of democratic transition in the sample, so we also test linear probability models with unit- and year-effects. ${ }^{94}$

Our argument implies that the influence of human rights prosecutions should vary by whether the autocratic regime is personalist. Roughly a third of the autocratic regimes in the sample are personalist dictatorships, and one-quarter (or 15 of 58) of these transition to democracy during the sample period. These regimes are scattered across the globe and include dictatorships - such as Belarus, Libya, Russia, Sudan, Togo, and Yemen - that lie in neighborhoods with relatively high human rights prosecutions as well as regimes in regions with few neighbor prosecutions - such as Madagascar, Malawi, and the Philippines in the 1980s and early 1990s.

We include a binary indicator of personalist dictatorship (Pers) and interact HRP with this variable: $H R P \times$ Pers. In the linear probability model, we include a constant $\left(\alpha_{0}\right)$, control variables $\left(X_{i, t-1}\right)$, as well as country $\left(\xi_{i}\right)$, year $\left(\tau_{t}\right)$, and duration time $\left(\zeta_{d}\right)$ 'fixed' effects: ${ }^{95}$

$$
Y_{i t}=\alpha_{0}+\beta_{1} \operatorname{Pers}_{i t}+\beta_{2} H R P_{i t}+\beta_{3} H R P \times \operatorname{Pers}_{t i}+\gamma X_{i, t-1}+\xi_{i}+\tau_{t}+\zeta_{d}+\varepsilon_{i, t}
$$

The marginal effect of human rights prosecutions in non-personalist regimes is estimated by $\beta_{2}$,

\footnotetext{
${ }^{93}$ The number of time periods is large (30), so this model is unlikely to suffer from an incidental parameters problem (Katz 2001). The average number of periods in the unbalanced panel is 21 .

${ }^{94}$ In the Appendix (Table A-1), we adopt a third approach, similar to a correlated random effects probit, that uses a binary dependent variable model but conditions the explanatory variables on their unit means (Wooldridge 2002, 487). This method preserves the binary dependent variable approach (unlike the linear probability model) but does not drop countries that experience no democratic transition. To obtain maximum likelihood convergence in this model, we adopt the same approach for year effects which reduces the number of parameters to be estimated.

${ }^{95}$ In the conditional logit, the country-effects are conditioned out, the constant is not estimated, and we substitute duration time polynomials for duration time dummies (Carter and Signorino 2010).
} 
whereas the linear combination of $\beta_{2}+\beta_{3}$ estimates this effect for personalist dictatorships.

We test a model that includes three control variables: neighbor democratization, neighbor postcivil war, and prior democracy. ${ }^{96}$ These variables capture diffusion processes that are correlated with both democratization and neighbor human rights prosecutions. We confirm the main results reported below in models that contain four additional control variables: $\log ($ GDP per capita), $\log$ (Population), Civil War, and Judicial Independence. ${ }^{97}$

\section{Results}

The first column of Table 1 reports the result from the conditional logit for the average effect across all autocracies; the coefficient is negative but not statistically different from zero. This estimate provides little evidence of any effect. Column (2) reports the model with the interaction term, the estimate of which is negative and statistically different from zero. The estimate for $H R P$ is positive but not significant, while the coefficient for $\beta_{H R P}+\beta_{H R P \times P e r s}$ is negative and significant. This suggests that the effect of prosecutions differs for the two groups of dictatorships; and consistent with our expectations, the estimated effect is negative for personalist regimes. The model in column (3) adds control variables and yields a stronger result.

The next three columns test linear probability models, yielding similar results with an expanded sample that includes countries where transition does not occur. The only notable difference in these models are the large and positive estimates for $H R P$ in models with the interaction term. This estimate, though not statistically significant, provides some evidence that prosecutions increase the prospects of democratic transition in non-personalist dictatorships. Figure 5 shows the substantive effect of the findings in columns (5) and (6). The vertical axis depicts the change in the estimated

\footnotetext{
${ }^{96}$ Neighbor democratization is a count of the number of neighboring countries that democratized in the past three years, and neighbor post-civil war is a count of the number of neighboring countries that experienced a post-civil war transition in past three years. Both measures use a binary cutpoint (4000km distance between capital cities) to mark neighbors. Prior democracy is a binary indicator of whether the incumbent regime was preceded by a democracy.

${ }^{97} \mathrm{GDP}$ and population data obtained from Maddison (Maddison 2010). Civil war is a categorical variable that takes a value of one for low-intensity conflict and a value of two for high-intensity conflict (Gleditsch et al. 2002). These three variables are lagged one year. Judicial independence is the lagged two-year moving average of the point estimates (Linzer and Staton 2011). Unreported models with no control variables $\left(X_{i, t-1}\right)$ yield similar results.
} 
Table 1: Human rights prosecutions and autocratic survival

\begin{tabular}{|c|c|c|c|c|c|c|}
\hline \multirow[t]{2}{*}{ Model } & \multicolumn{3}{|c|}{ Conditional logit } & \multicolumn{3}{|c|}{ Linear probability } \\
\hline & $(1)$ & $(2)$ & $(3)$ & $(4)$ & $(5)$ & $(6)$ \\
\hline HRP & -1.134 & 0.686 & 0.519 & 0.007 & 0.051 & 0.045 \\
\hline HRP $\times$ Pers & $(1.04)$ & $\begin{array}{c}(1.30) \\
-5.698^{* *} \\
(2.15)\end{array}$ & $\begin{array}{c}(1.49) \\
-6.918^{*} \\
(2.72)\end{array}$ & $(0.03)$ & $\begin{array}{c}(0.04) \\
-0.110^{*} \\
(0.05)\end{array}$ & $\begin{array}{c}(0.04) \\
-0.115^{*} \\
(0.05)\end{array}$ \\
\hline Personalist & $\begin{array}{c}-4.625^{* *} \\
(1.21)\end{array}$ & $\begin{array}{c}-3.341^{* *} \\
(1.22)\end{array}$ & $\begin{array}{c}-3.215^{*} \\
(1.47)\end{array}$ & $\begin{array}{c}-0.066^{*} \\
(0.03)\end{array}$ & $\begin{array}{c}-0.051+ \\
(0.03)\end{array}$ & $\begin{array}{l}-0.036 \\
(0.03)\end{array}$ \\
\hline Nbr democratic transitions & $\begin{array}{c}0.757+ \\
(0.42)\end{array}$ & $\begin{array}{l}0.617 \\
(0.42)\end{array}$ & $\begin{array}{l}0.757 \\
(0.50)\end{array}$ & $\begin{array}{l}0.010 \\
(0.01)\end{array}$ & $\begin{array}{l}0.011 \\
(0.01)\end{array}$ & $\begin{array}{l}0.009 \\
(0.01)\end{array}$ \\
\hline Nbr post-civil war transitions & $\begin{array}{l}0.088 \\
(0.63)\end{array}$ & $\begin{array}{l}0.106 \\
(0.62)\end{array}$ & $\begin{array}{c}1.415+ \\
(0.74)\end{array}$ & $\begin{array}{l}-0.010 \\
(0.01)\end{array}$ & $\begin{array}{l}-0.009 \\
(0.01)\end{array}$ & $\begin{array}{l}-0.006 \\
(0.01)\end{array}$ \\
\hline Prior democracy & $\begin{array}{l}-0.905 \\
(0.96)\end{array}$ & $\begin{array}{l}-1.286 \\
(1.03)\end{array}$ & $\begin{array}{l}-1.307 \\
(1.14)\end{array}$ & $\begin{array}{l}0.003 \\
(0.04)\end{array}$ & $\begin{array}{l}0.005 \\
(0.04)\end{array}$ & $\begin{array}{l}-0.001 \\
(0.03)\end{array}$ \\
\hline Log GDP per capita & & & $\begin{array}{l}-2.035 \\
(2.07)\end{array}$ & & & $\begin{array}{l}-0.016 \\
(0.02)\end{array}$ \\
\hline Log population & & & $\begin{array}{c}-27.453^{* *} \\
(9.68)\end{array}$ & & & $\begin{array}{c}-0.136^{* *} \\
(0.05)\end{array}$ \\
\hline Civil war & & & $\begin{array}{l}0.826 \\
(0.66)\end{array}$ & & & $\begin{array}{l}0.004 \\
(0.01)\end{array}$ \\
\hline Judicial independence & & & $\begin{array}{c}21.453^{* *} \\
(6.50)\end{array}$ & & & $\begin{array}{c}0.372^{* *} \\
(0.11)\end{array}$ \\
\hline Constant & & & & $\begin{array}{c}-0.044 \\
(0.03) \\
\end{array}$ & $\begin{array}{c}-0.062+ \\
(0.04) \\
\end{array}$ & $\begin{array}{l}1.235^{*} \\
(0.52) \\
\end{array}$ \\
\hline$\beta_{H R P}+\beta_{H R P \times P e r s}$ & & $\begin{array}{c}-5.012^{* *} \\
(1.90) \\
\end{array}$ & $\begin{array}{c}-6.399^{* *} \\
(2.41) \\
\end{array}$ & & $\begin{array}{l}-.060^{*} \\
(0.03) \\
\end{array}$ & $\begin{array}{l}-.070^{*} \\
(0.034) \\
\end{array}$ \\
\hline Countries & 54 & 54 & 53 & 108 & 108 & 108 \\
\hline Regimes & 91 & 91 & 87 & 174 & 174 & 171 \\
\hline Observations & 861 & 861 & 845 & 2304 & 2304 & 2294 \\
\hline In-sample transition probability & 0.076 & 0.076 & 0.075 & 0.028 & 0.028 & 0.028 \\
\hline Year FE & yes & yes & yes & yes & yes & yes \\
\hline Country FE & & & & yes & yes & yes \\
\hline Duration & Poly & Poly & Poly & $\mathrm{FE}$ & $\mathrm{FE}$ & $\mathrm{FE}$ \\
\hline
\end{tabular}


Linear probability model

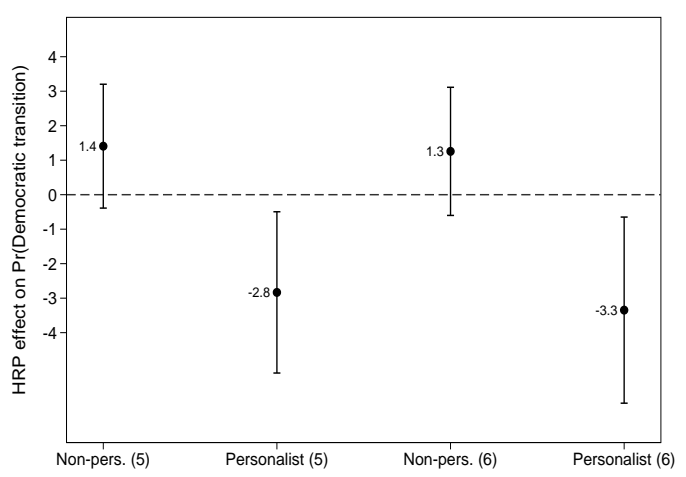

Figure 5: Neighbor human rights prosecutions (HRP) and democratic transition. The vertical axis marks the estimated change in the linear probability of democratic transition resulting from an increase in the level of neighbor HRPs from zero (the median) to one standard deviation above the mean. Errors bars depict the $90 \%$ confidence interval. The first two estimates are from column 5, Table 1; the last two are from column 6 (additional control variables).

linear probability of democratic transition resulting from an increase in neighbor prosecutions from zero to one standard deviation above the mean. ${ }^{98}$ The results from both models suggest that increasing HRPs reduces the chances of transition by roughly 3 percent in personalist regimes; in other regimes HRPs increase the probability of transition by just over 1 percent. $^{99}$

The main finding is robust to a number of changes to the specification. First, we test a binary dependent variable model that includes the unit- and year-means for all variables as proxies for unit- and year-fixed effects. This approach preserves the full sample (unlike a conditional logit), appropriately models a limited dependent variable (unlike the linear approach), yet conditions the parameters of interest on unit-effects and year-effects. This approach confirms the main result, and we also find a positive effect for prosecutions in non-personalist dictatorships (A-1). ${ }^{100}$ Second, we change the dependent variable to non-violent transition (A-4) or leadership change (A-3) instead of

\footnotetext{
${ }^{98}$ We calculate the in-sample mean and standard deviation for personalist and non-personalist regimes separately.

${ }^{99}$ Appendix Figure A-3 graphs the simulated effects from the conditional logit model in column (2). However, because the sample for these estimates drops half the countries (those that do not transition), the baseline probability of transition is biased upwards. The simulated effects suggest that an increase in HRPs reduces the likelihood of transitions by roughly one-half.

${ }^{100}$ Table A-2 reports results from a standard probit with no unit effects and from a random effects probit. The main results remain in each.
} 
democratic transition. Third, we employ an alternative measure of democratic transition (A-5). ${ }^{101}$ Fourth, instead of using year-fixed effects we include the global trend in HRPs or region specific time trends (A-6). Fifth, we alter the lag on the main variable of interest to two- or four-year lagged counts for prosecutions (A-7). The main result remains irrespective of these changes.

Next, we constructed a measure of 'religious neighbor' as an alternative weight for the HRP variable. ${ }^{102}$ Instead of relying on geographic proximity, this variable uses information on the share of citizens who belong to a particular religion (Buddhist, Catholic, Hindu, Muslim, Orthodox, and Protestant). 'Neighbors' are defined as countries that have similar majority religion. ${ }^{103}$ Results using this measure are consistent with the main findings (A-8). ${ }^{104}$

Finally, to understand whether these findings depend on cases from one particular geographic region, we test model 2 while excluding one geographic region at a time. Because much of the existing evidence supporting the optimistic view of human rights prosecutions draws on Latin American countries, ${ }^{105}$ and recent research suggests that there is a regional bias in information about human rights abuses that favors Latin America, ${ }^{106}$ we examine whether the result relies on information from just one region. Table 2 reports the findings from conditional logit models; ${ }^{107}$ with the first column reporting the model with all regions included for comparison. The estimates for HRPs in personalist dictatorships are similar across all models, though this estimate is stronger once sub-Saharan African dictatorships are excluded from the sample. For HRPs in non-personalist dictatorships, we find a positive though not statistically significant result for all models, except the one that excludes Central America and the Caribbean. This suggests that while the main finding is robust to the exclusion of any one region from the analysis, any positive evidence from nonpersonalist dictatorships reflects information from Central American and Caribbean dictatorships.

${ }^{101}$ Cheibub, Gandhi and Vreeland 2010 .

${ }^{102}$ Kim 2012.

${ }^{103}$ Data on religion are from La Porta et al. 1999 with updates from the United Nations. This is a cross-sectional measure.

${ }^{104}$ The linear probability model, while yielding a strong negative coefficient for the interaction term, indicates that prosecutions have a large positive effect in non-personalist regimes but small negative effect in personalist ones.

${ }^{105}$ Lutz and Sikkink 2001; Sikkink and Walling 2007.

${ }^{106}$ Hafner-Burton and Ron 2013.

${ }^{107}$ To obtain convergence with smaller samples, we use five time period dummies, not year effects. 


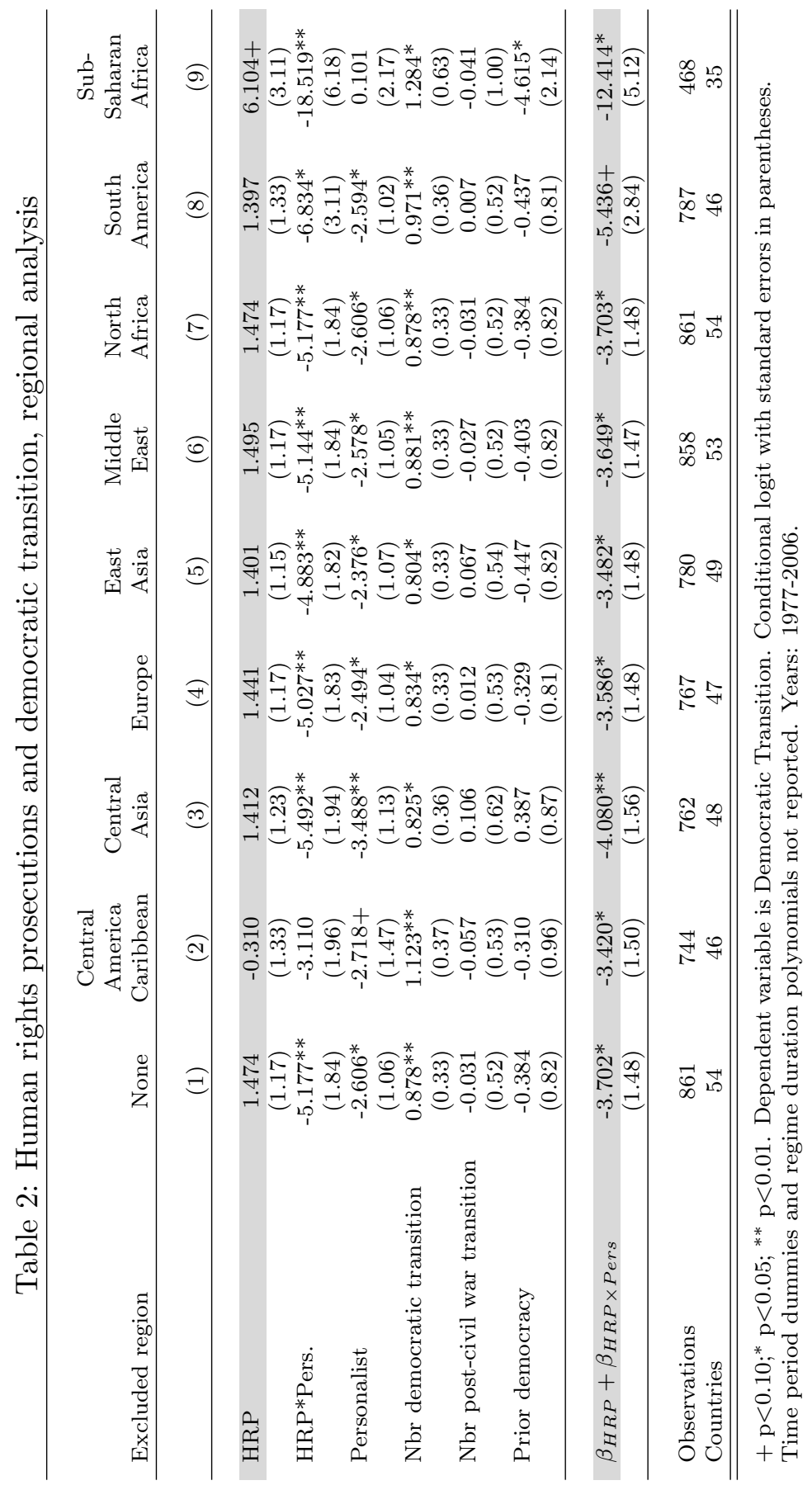




\section{Discussion}

The logic of both the optimistic and pessimistic approaches rests on the assumption that prosecutions are costly to the perpetrators of repression. Proponents focus on how the threat of punishment deters repression in the future. This argument has implications for an autocratic regime's capacity to pursue repression as a tool to survive regime crises in the future. By increasing the chances leaders of the repressive appartus defect, human rights prosecutions might lower the utility of remaining in power in the current period. Conversely, critics of human rights prosecutions focus on the possibility that punishment in post-transition settings sends a signal to elites in repressive regimes that they are more likely to be punished if they transition to democracy. This logic suggests that prosecutions could deter dictatorships from relinquishing power.

We argue that the domestic political context helps us understand which of these mechanisms is likely to predominate. In dictatorships where autocratic elites can retain some post-transition power to protect their interests, the prospects of punishment after transition should be lower. Thus the logic of the critics is less likely to pinch in these settings. Further, these are the same dictatorships where the repressive apparatus of the regime is less likely to be personally tied to the regime leader. This means that repressive agents are likely to be more sensitive to changes in the costliness of domestic repression and therefore more likely to defect from the regime during crises.

Our theory emphasizes the importance of exit guarantees that are made more credible when the political power of former autocratic elites endures after regime transition. We observe differences in enduring power based on distinctions among domestic institutions in different autocratic contexts, which we measure using a qualitative characteristic of autocratic regimes. ${ }^{108}$ This approach builds on recent research in international relations that distinguishes among autocracies to better understand domestic audience costs, alliance commitments, the political consequences of defeat in war, and the selection of belligerent leaders. ${ }^{109}$

An alternative logic, based on the size of the coalition that supports the dictatorship, suggests that it might be easier to credibly guarantee immunity after transition for a relatively small group

${ }^{108}$ Huntington 1991 and Geddes 1999.

${ }^{109}$ Weeks 2008; Leeds, Mattes and Vogel 2009; Debs and Goemans 2010; Weeks 2012. 
of elites. Democratic governments that arise from large coalition dictatorships, on the other hand, might face more difficulties in making credible promises to a large number of coalition elites. Mapping this intuition onto autocratic regime types suggests that it might therefore be easier to make credible promises to a handful of elites in personalist dictatorships - the opposite of our expectation. We find little evidence consistent with this argument, but it nonetheless offers a promising new avenue for future research by pointing to the absolute number of individuals who might be persuaded by ex-ante exit guarantees.

Finally, our analysis largely skirts the issue of repression. The logic of the pessimistic view suggests that past repression is a sunk cost, which should influence how an autocratic regime behaves as it confronts the reality of increasing human rights prosecutions over time. ${ }^{110}$ Thus a next step in this research might examine how prosecutions influence transitions, conditional on regime repression. If the logic of the critics is correct, we should observe a stronger deterrent to transition in regimes with a more repressive history. However, this task is complicated by the fact that the most widely used data sets on repression ${ }^{111}$ rely on information from organizations such as Amnesty International and the U.S. State Department - that strategically pursue human rights shaming campaigns and advocate for human rights prosecutions. This makes it difficult to disentangle observed repression from the shaming and punishment strategies of international actors.

\section{Conclusion}

This paper assesses whether domestic and international criminal prosecutions for human rights abuses deter dictatorships from leaving power. We argue that the influence of human rights prosecutions should vary by whether the incumbent autocratic regime has institutionalized post-exit guarantees. In autocracies where former elites are more likely to have credible guarantees of their interests - including protections from prosecution - we expect externally-generated increases in the probability of punishment to have little deterrent effect. However, in dictatorships that lack a dominant party or institutionalized military that can preserve post-transition leverage, we expect human rights prosecutions to deter dictators from giving up power.

${ }^{110}$ Sutter 2006.

${ }^{111}$ The Political Terror Scale (PTS) and the Cingranelli-Richards (CIRI) Human Rights Dataset. 
To test this argument, we use human rights prosecutions in neighboring countries as a proxy for changes in the expectation of punishment should an autocratic regime relinquish power. The evidence for an average effect across all autocraties in the past three decades is inconclusive. However, human rights prosecutions are associated with a decreased risk of democratic transition in personalist dictatorships that typically lack institutionalized post-transition guarantees.

At first glance, our results for human rights prosecutions might appear to be at odds with the finding that these prosecutions reduce repression in transition countries. ${ }^{112}$ The reason underlying both, however, may be the same: human rights prosecutions increase the costs of repression. These findings can be reconciled once we consider the time inconsistency problem in the optimal treatment of dictators. ${ }^{113}$ Ideally, we would like to punish dictators severely to deter future repression. Kim and Sikkink provide evidence consistent with this logic, warranting optimism for the future of international campaigns to prosecute repressive dictators.

However, we also want dictators to leave power peacefully, preferably in a transition leading to democracy. Credible guarantees of amnesty may lower the cost of leaving power, thereby inducing departure. Personalist dictators, as Huntington pointed out two decades ago, are the least likely to have institutional guarantees of their interests after a transition. ${ }^{114}$ For dictators who have already committed human rights abuses, the costs of repression are sunk costs; they cannot undo them once the international regime changes and begins punishing autocratic elites after a transition. For these rulers, prosecutions in other countries simply raise the costs of exit. That the evidence is strongest for personalist dictators suggests exit guarantees may be the link between observing punishment and clinging to power. These autocrats do not have institutional guarantees - either a strong party or a threatening military - to ensure a happy post-exit fate. Criminal prosecution of their colleagues may only make them view retirement all the more dimly.

\section{References}

Acemoglu, Daron and James Robinson. 2006. Economic Origins of Dictatorship and Democracy. New York: Cambridge University Press.

\footnotetext{
${ }^{112}$ Kim and Sikkink 2010.

${ }^{113}$ Sutter 1995, 126.

${ }^{114}$ Huntington 1991.
} 
Barany, Zoltan. 2011. "Comparing Arab Revolts: The Role of the Military." Journal of Democracy $22(4): 24-35$.

Bellin, Eva. 2004. "The Robustness of Authoritarianism in the Middle East: Exceptionalism in Comparative Perspective." Comparative Politics 36(2):139-157.

Bellin, Eva. 2012. "Reconsidering the Robustness of Authoritarianism in the Middle East: Lesson from the Arab Spring." Comparative Politics 44(2):127-149.

Boix, Carles. 2003. Democracy and Redistribution. New York: Cambridge University Press.

Boix, Carles and Milan Svolik. 2013. "Foundations of Limited Authoritarian Government: Institutions, Commitment, and Power-sharing in Dictatorships." Journal of Politics 75(2):300-316.

Bratton, Michael and Nicolas van de Walle. 1994. "Neopatrimonial Regimes and Political Transitions in Africa." World Politics 46(4):453-489.

Brinks, Daniel and Michael Coppedge. 2006. "Diffusion Is No Illusion: Neighbor Emulation in the Third Wave of Democracy." Comparative Political Studies 39(4):463-489.

Brownlee, Jason. 2007. Authoritarianism in an Age of Democratization. New York: Cambridge University Press.

Carter, David and Curt Signorino. 2010. "Back to the Future: Modeling Time Dependence in Binary Data." Political Analysis 18(3):271-292.

Chehabi, H. E. and Juan J. Linz. 1998. Sultanistic Regimes. Baltimore, MD: The Johns Hopkins University Press.

Cheibub, José A., Jennifer Gandhi and James R. Vreeland. 2010. "Democracy and Dictatorship Revisited." Public Choice 143(1-2):67-101.

David, Roman. 2003. "Lustration Laws in Action: The Motives and Evaluation of Lustration Policy in the Czech Republic and Poland." Law and Social Inquiry 28(2):387-439.

Debs, Alexandre and Hein E. Goemans. 2010. "Regime Type, the Fate of Leaders, and War." American Political Science Review 104(3):430-445.

Dix, Robert H. 1982. "The Breakdown of Authoritarian Regimes." The Western Political Quarterly $35(4): 554-573$.

Escribà-Folch, Abel. 2013. "Accountable for What? Regime Types, Performance, and the Fate of Outgoing Dictators, 1946-2004." Democratization 20(1):160-185.

Frantz, Erica and Natasha Ezrow. 2011. The Politics of Dictatorship: Institutions and Outcomes in Authoritarian Regimes. Boulder: Lynne Rienner Publishers.

Gandhi, Jennifer. 2008. Political Institutions under Dictatorship. New York: Cambridge University Press.

Geddes, Barbara. 1999. "What Do We Know About Democratization After Twenty Years?" Annual Review of Political Science 2:115-144. 
Geddes, Barbara, Joseph Wright and Erica Frantz. 2014. "Autocratic Breakdown and Regime Transitions: A New Data Set." Perspectives on Politics 14:forthcoming.

Gilligan, Michael J. 2006. "Is Enforcement Necessary for Effectiveness? A Model of the International Crime Regime." International Organization 60(4):935-967.

Ginsburg, Tom. 2009. "The Clash of Commitments at the International Criminal Court." Chicago Journal of International Law 9:499-514.

Gleditsch, Kristian Skrede and Michael D. Ward. 2006. "Diffusion and the International Context of Democratization." International Organization 6(4):911-933.

Gleditsch, Nils Tetter, Peter Wallensteen, Mikael Eriksson, Margareta Sollenberg, and Havard Strand. 2002. "Armed Conflict 1946-2001: A New Dataset." Journal of Peace Research 39(5):615637.

Goemans, Hein, Kristian Skrede Gleditsch and Giacomo Chiozza. 2009. "Introducting Archigos: A Dataset of Political Leaders." Journal of Peace Research 46(2):269-283.

Goldsmith, Jack. 2003. "The Self-Defeating International Criminal Court." University of Chicago Law Review 70(1):89-104.

Goldsmith, Jack and Stephen D. Krasner. 2003. "The Limits of Idealism.” Daedalus 132(1):47-63.

Greene, Kenneth F. 2010. "The Political Economy of Authoritarian Single Party Dominance." Comparative Political Studies 43(9):1-27.

Haas, Peter M. 1992. "Introduction: Epistemic Communities and International Policy Coordination." International Organization 46(1):1-35.

Hafner-Burton, Emilie and James Ron. 2013. "The Latin Bias: Regions, the Anglo-American Media, and Human Rights." International Studies Quarterly forthcoming.

Hafner-Burton, Emilie M. and James Ron. 2009. "Seeing Double: Human Rights Impact through Qualitative and Quantitative Eyes." World Politics 61(2):360-401.

Haggard, Stephen and Kaufman. 1995. Political Economy of Democratic Transitions. Princeton: Princeton University Press.

Hawkins, Darren. 2002. International Human Rights and Authoritarian Rule in Chile. Lincoln: University of Nebraska Press.

Hollyer, James R. and B. Peter Rosendorff. 2011. "Why Do Authoritarian Regimes Sign the Convention Against Torture? Signaling, Domestic Politics and Non-Compliance." Quarterly Journal of Political Science 6(3-4):275-327.

Human Rights Watch. 2010. "ICC: Bashir Warrant Is Warning to Abusive Leaders." 3 February 2010.

Human Rights Watch. 2012. "Senegal: Proceedings Against Hissène Habré Draw Near." 19 December 2012. 
Huntington, Samuel P. 1991. "How Countries Democratize." Political Science Quarterly 106(4):579616.

Ishiyama, John T. 1995. "Communist Parties in Transition: Structures, Leaders, and Processes of Democratization in Eastern Europe." Comparative Politics pp. 147-166.

Katz, Ethan. 2001. "Bias in Conditional and Unconditional Fixed Effects Logit Estimation." Political Analysis 9(4):379-384.

Keck, Margaret E. and Kathryn Sikkink. 1998. Activists Beyond Borders. Ithaca: Cornell University Press.

Kim, Hun Joon. 2012. "Structural Determinants of Human Rights Prosecutions after Democratic Transition." Journal of Peace Research 49(2):305-320.

Kim, Hun Joon and Kathryn Sikkink. 2010. "Explaining the Deterrence Effect of Human Rights Prosecutions for Transitional Countries." International Studies Quarterly 54(4):939-963.

La Porta, R., F. López de Silanes, A. Shleifer and R. Vishny. 1999. "The Quality of Government." Journal of Law, Economics and Organization 15(1):222-279.

Leeds, Brett Ashley, Michaela Mattes and Jeremy S. Vogel. 2009. "Interests, Institutions, and the Reliability of International Commitments." American Journal of Political Science 53(2):461-476.

Linz, Juan and Alfred Stepan. 1996. Problems of Democratic Transition and Consolidation. Baltimore: The Johns Hopkins University Press.

Linzer, Drew A. and Jeffrey K. Staton. 2011. "A Measurement Model for Synthesizing Multiple Comparative Indicators: The Case of Judicial Independence." Prepared for presentation at the 2011 Annual Meeting of the American Political Science Association, September 1-4, Seattle, Washington.

Lust-Okar, Ellen. 2005. Structuring Conflict in the Arab World. Incumbents, Opponents, and Institutions. Cambridge: Cambridge University Press.

Lutz, Ellen L. and Kathryn Sikkink. 2001. "The Justice Cascade: The Evolution and Impact of Foreign Human Rights Trials in Latin America." Chicago Journal of International Law 2(1):1-34.

Maddison, Angus. 2010. "World Population, GDP and Per Capita GDP, 1-2008 AD." available at http://www.ggdc.net/maddison.

Magaloni, Beatriz. 2006. Voting for Autocracy: Hegemonic Party Survival and its Demise in Mexico. Cambridge: Cambridge University Press.

Magaloni, Beatriz. 2008. "Credible Power-Sharing and the Longevity of Authoritarian Rule." Comparative Political Studies 41(4-5):715-741.

Méndez, Juan E. 1997. “Accountability for Past Abuses." Human Rights Quarterly 19(2):255-282.

Meseguer, Covadonga. 2009. Learning, Policy Making and Market Reforms. New York: Cambridge University Press. 
Morrison, Kevin. 2009. "Oil, Non-Tax Revenue, and the Redistributional Foundations of Regime Stability." International Organization 63(1):107-138.

Nalepa, Monika. 2010. Skeletons in the closet: transitional justice in post-Communist Europe. New York: Cambridge University Press.

Nalepa, Monika and Emilia J. Powell. 2011. "To Stay or to Go: Decision Making on the Peaceful Surrender of Control after the International Criminal Court." Unpublished manuscript.

Nobles, Melissa. 2010. "The Prosecution of Human Rights Violations." Annual Review of Political Science 13(1):165-182.

Nordlinger, Eric. 1977. Soldiers in politics: military coups and governments. Englewood Cliffs, NJ: Prentice Hall.

O'Donnell, Guillermo and Philippe Schmitter. 1986. Transitions from Authoritarian Rule: Tentative Conclusions about Uncertain Democracies. Baltimore: Johns Hopkins University Press.

Olsen, Tricia D., Leigh A. Payne and Andrew G. Reiter. 2010. "The Justice Balance: When Transitional Justice Improves Human Rights and Democracy." Human Rights Quarterly 32(4):980-1007.

Osiel, Mark J. 2000. "Why Prosecute? Critics of Punishment for Mass Atrocity." Human Rights Quarterly 22(1):118-147.

Pevehouse, Jon C. 2002. "Democracy from the Outside-In? International Organizations and Democratization." International Organization 56(3):515-549.

Przeworski, Adam. 1991. Democracy and the Market. Political and Economic Reforms in Eastern Europe and Latin America. New York: Cambridge University Press.

Przeworski, Adam, Michael E. Alvarez, Jose A. Cheibub and Fernando Limongi. 2000. Democracy and Development: Political Institutions and Well-Being in the World, 1950-1990. New York: Cambridge University Press.

Quinlivan, James T. 1999. "Coup-Proofing: Its Practice and Consequences in the Middle East." International Security 24(2):131-165.

Rice, Xan. 2009. "Sudanese president Bashir charged with Darfur war crimes." The Guardian .

Ritter, Emily and Scott Wolford. 2012. "Pre-Arrest Bargaining and the Effectiveness of International Criminal Regimes." Journal of Theoretical Politics 24(2):149-171.

Roht-Arriaza, Naomi. 2005. The Pinochet Effect: Transnational Justice in the Age of Human Rights. Philadelphia: University of Pennsylvania Press.

Sikkink, Kathryn. 2011. The Justice Cascade: How Human Rights Prosecutions Are Changing World Politics. New York: W. W. Norton \& Company.

Sikkink, Kathryn and Carrie Walling. 2007. "The Impact of Human Rights Trials in Latin America." Journal of Peace Research 44(4):427-445. 
Skaar, Elin. 1999. "Truth Comissions, Trials, or Nothing? Policy Options in Democratic Transitions." Third World Quarterly 20(6):1109-1128.

Smith, Benjamin. 2005. "Life of the Party: The Origins of Regime Breakdown and Persistence under Single-Party Rule." World Politics 57(3):421-451.

Snyder, Jack and Leslie Vinjamuri. 2004. "Trials and Errors: Principle and Pragmatism in Strategies of International Justice." International Security 28(3):5-44.

Snyder, Richard. 1992. "Explaining Transitions from Neopartimonial Dictatorships." Comparative Politics 24(4):379-399.

Stanton, Gregory H. 2009. "Should President Omar al-Bashir of Sudan Be Charged and Arrested by the International Criminal Court? An Exchange of Views." Genocide Studies and Prevention $4(3): 329-353$.

Stepan, Alfred. 1971. The Military in Politics: Changing Patterns in Brazil. Princeton: Princeton University Press.

Stephan, Maria J. and Erica Chenoweth. 2008. "Why Civil Resistance Works. The Strategic Logic of Nonviolent Conflict." International Security 33(1):7-44.

Sutter, Daniel. 1995. "Settling Old Scores: Potholes along the Transition from Authoritarian Rule." Journal of Conflict Resolution 39(1):110-128.

Sutter, Daniel. 2006. "The Deterrent Effects of the International Criminal Court." Conferences on New Political Economy 23(1):9-24.

Svolik, Milan. 2011. "Moral Hazard in Authoritarian Repression and the Fate of Dictators." The Political Economist 13(2):7-9.

Teorell, Jan. 2010. Determinants of Democratization: Explaining Regime Change in the World, 1972-2006. Cambridge: Cambridge University Press.

Thompson, William R. 1975. "Regime Vulnerability and the Military Coup." Comparative Politics $7(4): 459-487$.

Weeks, Jessica. 2008. "Autocratic Audience Costs: Regime Type and Signaling Resolve." International Organization 62(1):35-64.

Weeks, Jessica L. 2012. "Strongmen and Straw Men: Authoritarian Regimes and the Initiation of International Conflict." American Political Science Review 106(2):326-347.

Weyland, Kurt. 2005. "Theories of Policy Diffusion: Lessons from Latin American Pension Reform." World Politics 57(2):262-295.

Wooldridge, Jeffrey M. 2002. Econometric Analysis of Cross Section and Panel Data. Cambridge MA: MIT Press.

Wright, Joseph. 2008. "Do Authoritarian Institutions Constrain? How Legislatures Impact Economic Growth and Investment." American Journal of Political Science 52(2):322-343. 
Wright, Joseph and Abel Escribà-Folch. 2012. "Authoritarian Institutions and Regime Survival: Transitions to Democracy and Subsequent Authoritarian Regimes." British Journal of Political Science 42(2):283-309. 


\section{Supplementary Material (online appendices)}

Summary Statistics \& Data Sources p. 38

Sample Autocratic regimes, 1977-2006 p. 39

Table A-1 Correlated RE

p. 41

Table A-2 No unit fixed effects

p. 42

Table A-3 Autocratic leader failure

p. 43

Table A-4 Non-violent regime transitions

p. 44

Table A-5 Cheibub, Gandhi, and Vreeland (2010) democratic transitions

p. 45

Table A-6

Alternative specifications for modeling calendar time trends

p. 46

Table A-7

Alternative lags for the HRP variable

p. 47

Table A-8 Religious neighbors

p. 48

Figure A-1 Weighted neighbor prosecutions index

p. 49

Figure A-2 Regional neighbor prosecutions and democratization

p. 50

Figure A-3 Conditional logit simulation

p. 51

Figure A-4 Interaction term, by distance cut points.

p. 52 


\section{Summary Statistics and Data Sources}

\begin{tabular}{|c|c|c|c|c|c|c|}
\hline Variable & $\mathrm{N} \times \mathrm{T}$ & Mean & StDev & Min & $\operatorname{Max}$ & Source \\
\hline Regime Failure & 2304 & 0.05 & 0.22 & 0 & 1 & updated Geddes (2003) \\
\hline Democratic Transition & 2304 & 0.03 & 0.16 & 0 & 1 & updated Geddes (2003) \\
\hline Non-violent Transition & 2304 & 0.03 & 0.17 & 0 & 1 & updated Geddes (2003) \\
\hline Regime Duration & 2304 & 22.1 & 17.9 & 1 & 88 & updated Geddes (2003) \\
\hline Personalist Dictatorship & 2304 & 0.29 & 0.45 & 0 & 1 & updated Geddes (2003) \\
\hline $\mathrm{HRP}$ & 2304 & 0.11 & 0.23 & 0 & 1.64 & Kim \& Sikkink (2010) \\
\hline Neighbor Democratization & 2304 & 0.68 & 0.63 & 0 & 2.30 & updated Geddes (2003) \\
\hline Neighbor Civil war & 2304 & 0.69 & 0.69 & 0 & 2.40 & Gleditsch et al. (2002) \\
\hline $\log (\mathrm{GDPpc})_{t-1}$ & 2303 & 7.58 & 0.92 & 5.33 & 10.23 & Maddison (2010) \\
\hline $\log (\text { Population })_{t-1}$ & 2303 & 9.23 & 1.37 & 6.28 & 14.08 & Maddison (2010) \\
\hline Civil War ${ }_{t-1}$ & 2304 & 0.28 & 0.60 & 0 & 2 & Gleditsch et al. (2002) \\
\hline Previous Democracy & 2304 & 0.17 & 0.38 & 0 & 1 & updated Geddes (2003) \\
\hline Judicial Indepndence $t-1, t-2$ & 2295 & 0.21 & 0.12 & .02 & 0.66 & Linzer \& Staton (2012) \\
\hline
\end{tabular}

61 of 174 (or $35 \%$ ) sample regimes are personalist post-1999, 31 of 73 (or $42 \%$ ) regimes are personalist 
Sample Autocracies, 1977-2006

\begin{tabular}{|c|c|c|c|}
\hline Afghanistan & $1977-1978$ & Congo-Brz & $1977-1991$ \\
\hline Afghanistan & $1979-1992$ & Congo-Brz & $1998-2006$ \\
\hline Afghanistan & $1997-2001$ & Cuba & $1977-2006$ \\
\hline Albania & $1977-1991$ & Czechoslovakia & $1977-1989$ \\
\hline Algeria & $1977-1992$ & Dominican Rep & $1977-1978$ \\
\hline Algeria & $1993-2006$ & Ecuador & $1977-1979$ \\
\hline Angola & $1977-2006$ & Egypt & $1977-2006$ \\
\hline Argentina & $1977-1983$ & El Salvador & $1977-1982$ \\
\hline Armenia & $1996-1998$ & El Salvador & $1983-1994$ \\
\hline Armenia & $1999-2006$ & Ethiopia & $1977-1991$ \\
\hline Azerbaijan & $1992-1992$ & Ethiopia & $1992-2006$ \\
\hline Azerbaijan & $1994-2006$ & Gabon & $1977-2006$ \\
\hline Bangladesh & $1977-1982$ & Gambia & $1977-1994$ \\
\hline Bangladesh & $1983-1990$ & Gambia & $1995-2006$ \\
\hline Belarus & $1992-1994$ & Georgia & $1992-1992$ \\
\hline Belarus & $1995-2006$ & Georgia & $1993-2003$ \\
\hline Benin & $1977-1990$ & Ghana & $1977-1979$ \\
\hline Bolivia & $1977-1979$ & Ghana & $1982-2000$ \\
\hline Bolivia & $1981-1982$ & Guatemala & $1977-1985$ \\
\hline Botswana & $1977-2006$ & Guatemala & $1986-1995$ \\
\hline Brazil & $1977-1985$ & Guinea Bissau & $1977-1980$ \\
\hline Bulgaria & $1977-1990$ & Guinea Bissau & $1981-1999$ \\
\hline Burkina Faso & $1977-1980$ & Guinea Bissau & $2003-2003$ \\
\hline Burkina Faso & $1981-1982$ & Guinea & $1977-1984$ \\
\hline Burkina Faso & $1983-1987$ & Guinea & $1985-2006$ \\
\hline Burkina Faso & $1988-2006$ & Haiti & $1977-1986$ \\
\hline Burundi & $1977-1987$ & Haiti & $1987-1988$ \\
\hline Burundi & $1988-1993$ & Haiti & $1989-1990$ \\
\hline Burundi & $1997-2003$ & Haiti & $1992-1994$ \\
\hline Cambodia & $1977-1979$ & Haiti & $2000-2004$ \\
\hline Cambodia & $1980-2006$ & Honduras & $1977-1981$ \\
\hline Cameroon & $1977-1983$ & Hungary & $1977-1990$ \\
\hline Cameroon & $1984-2006$ & Indonesia & $1977-1999$ \\
\hline Cen African Rep & $1977-1979$ & Iran & $1977-1979$ \\
\hline Cen African Rep & $1980-1981$ & Iran & $1980-2006$ \\
\hline Cen African Rep & $1982-1993$ & Iraq & $1977-1979$ \\
\hline Cen African Rep & $2004-2006$ & Iraq & $1980-2003$ \\
\hline Chad & $1977-1979$ & Ivory Coast & $1977-1999$ \\
\hline Chad & $1983-1990$ & Ivory Coast & $2000-2000$ \\
\hline Chad & $1991-2006$ & Ivory Coast & $2001-2006$ \\
\hline Chile & $1977-1989$ & Jordan & $1977-2006$ \\
\hline China & $1977-2006$ & Kazakhstan & $1992-2006$ \\
\hline Congo/Zaire & $1977-1997$ & Kenya & $1977-2002$ \\
\hline Congo/Zaire & $1998-2006$ & Korea North & $1977-2006$ \\
\hline
\end{tabular}

$\begin{array}{ll}\text { Korea South } & 1977-1987 \\ \text { Kuwait } & 1977-2006 \\ \text { Kyrgyzstan } & 1992-2005 \\ \text { Kyrgyzstan } & 2006-2006 \\ \text { Laos } & 1977-2006 \\ \text { Lesotho } & 1977-1986 \\ \text { Lesotho } & 1987-1993 \\ \text { Liberia } & 1977-1980 \\ \text { Liberia } & 1981-1990 \\ \text { Liberia } & 1998-2003 \\ \text { Libya } & 1977-2006 \\ \text { Madagascar } & 1977-1993 \\ \text { Malawi } & 1977-1994 \\ \text { Malaysia } & 1977-2006 \\ \text { Mali } & 1977-1991 \\ \text { Mauritania } & 1977-1978 \\ \text { Mauritania } & 1979-2005 \\ \text { Mauritania } & 2006-2006 \\ \text { Mexico } & 1977-2000 \\ \text { Mongolia } & 1977-1993 \\ \text { Morocco } & 1977-2006 \\ \text { Mozambique } & 1977-2006 \\ \text { Myanmar } & 1977-1988 \\ \text { Myanmar } & 1989-2006 \\ \text { Namibia } & 1991-2006 \\ \text { Nepal } & 1977-1991 \\ \text { Nepal } & 2003-2006 \\ \text { Nicaragua } & 1977-1979 \\ \text { Nicaragua } & 1980-1990 \\ \text { Niger } & 1977-1991 \\ \text { Niger } & 1997-1999 \\ \text { Nigeria } & 1977-1979 \\ \text { Nigeria } & 1984-1993 \\ \text { Nigeria } & 1994-1999 \\ \text { Oman } & 1977-2006 \\ \text { Pakistan } & 1977-1977 \\ \text { Pakistan } & 1978-1988 \\ \text { Pakistan } & 2000-2006 \\ \text { Panama } & 1977-1982 \\ \text { Panama } & 1983-1989 \\ \text { Paraguay } & 1977-1993 \\ \text { Peru } & 1977-1980 \\ \text { Peru } & 1993-2000 \\ \text { Philippines } & 1977-1986 \\ & \end{array}$

Poland

Romania

Russia

Rwanda

Saudi Arabia

Senegal

Sierra Leone

Sierra Leone

Sierra Leone

Singapore

Somalia

South Africa

Soviet Union

Sri Lanka

Sudan

Sudan

Sudan

Swaziland

Syria

Taiwan

Tajikistan

Tanzania

Thailand

Thailand

Togo

Tunisia

Turkey

Turkmenistan

UAE

Uganda

Uganda

Uganda

Uruguay

Uzbekistan

Vietnam

Yemen

Yemen

Yugoslavia

Zambia

Zambia

Zimbabwe
1977 - 1989 1977 - 1989

$1994-2006$

1995 - 2006

1977 - 2006

1977 - 2000

1977 - 1992

1993 - 1996

$1998-1998$

1977 - 2006

1977 - 1991

1977 - 1994

1977 - 1991

$1979-1994$

1977 - 1985

1986 - 1986

1990 - 2006

1977 - 2006

1977 - 2006

1977 - 2000

1992 - 2006

$1977-2006$

1977 - 1988

$1992-1992$

1977 - 2006

1977 - 2006

1981 - 1983

$1992-2006$

1977 - 2006

1977 - 1979

$1981-1985$

$1987-2006$

1977 - 1984

1992 - 2006

1977 - 2006

1977 - 1978

1979 - 2006

1977 - 1990

$1977-1991$

1997 - 2006

1981 - 2006 
The two estimators employed in the main text are a conditional logit and a linear model with country fixed-effects. A conditional logit model drops roughly half of the regimes from the sample that do not transition to democracy between 1977 and 2006, ${ }^{115}$ while a linear model assumes unbounded values for the dependent variable, which is binary.

Readers may prefer to see the results from an approach that circumvents each of these issues. We therefore use a limited dependent variable model, but condition the estimates on the unit means of both the explanatory and the dependent variables. ${ }^{116}$ Note that a linear fixed effects model does the exact same data transformation, but with a different (i.e. linear) link function.

$$
\operatorname{Pr}\left(Y_{t}=1 \mid Y_{t-1}=0\right)=\alpha_{j[i]}+\beta X_{i, t-1}+\theta \bar{X}_{i}+\vartheta \bar{Y}_{i}+\varepsilon_{i, t}
$$

When unit random effects are added to this model, Wooldridge 2002, 487 calls this approach "Chamberlain's random effects probit" to distinguish it from the traditional random effects probit (with no unit means). Appendix Table A-1 reports the estimates from this model with an additional set of parameters for the year-means of each variable to "mimic" year fixed effects:

$$
\operatorname{Pr}\left(Y_{t}=1 \mid Y_{t-1}=0\right)=\alpha_{j[i]}+\beta X_{i, t-1}+\theta \bar{X}_{i}+\vartheta \bar{Y}_{i}+\phi \bar{X}_{t}+\varphi \bar{Y}_{t}+\varepsilon_{i, t} ; \quad \alpha_{j} \sim N\left(\mu_{\alpha}, \sigma_{\alpha}^{2}\right) ; \quad \varepsilon_{i, t} \sim N\left(0, \sigma_{y}^{2}\right)
$$

We estimate this model in Stata version 12 with the gllamm package which allows us to include unit random effects as well as cluster the errors on units (the xtprobit command does not allow simultaneous random effects and clustered errors). The estimates are substantively the same as those reported in the main text, with the exception that the estimate for the HRP coefficient is now positive and statistically different from zero. ${ }^{117}$

\footnotetext{
${ }^{115} 83$ of 174 , or 48 percent, of regimes in the sample are in countries that do not have a democratic transition during the sample period.

${ }^{116}$ Note that the estimates of the parameters of interest, $\beta$, are the same irrespective of whether we use demeaned variables or not. Whether the time-varying information is demeaned or not will, however, affect the estimates of $\theta$.

${ }^{117}$ In an earlier version of this paper, we showed that the results using this approach are robust to all the specification changes contained Tables A-3 to A-8 in this Appendix.
} 
Table A-1: Unit- and Year-means probit model

\begin{tabular}{|c|c|c|}
\hline & $(1)$ & $(2)$ \\
\hline HRP & $\begin{array}{l}0.417 \\
(0.44)\end{array}$ & $\begin{array}{c}1.112+ \\
(0.59)\end{array}$ \\
\hline HRP $\times$ Pers & & $\begin{array}{c}-2.470^{* *} \\
(0.81)\end{array}$ \\
\hline Personalist & $\begin{array}{c}-1.324^{*} \\
(0.59)\end{array}$ & $\begin{array}{c}-0.882 \\
(0.59)\end{array}$ \\
\hline Nbr democratic transitions & $\begin{array}{c}0.391^{*} \\
(0.18)\end{array}$ & $\begin{array}{c}0.404^{*} \\
(0.17)\end{array}$ \\
\hline Nbr post-civil war transitions & $\begin{array}{l}-0.167 \\
(0.20)\end{array}$ & $\begin{array}{c}-0.159 \\
(0.21)\end{array}$ \\
\hline Prior democracy & $\begin{array}{l}0.035 \\
(0.38)\end{array}$ & $\begin{array}{l}0.023 \\
(0.38)\end{array}$ \\
\hline Constant & $\begin{array}{c}-3.598^{* *} \\
(0.92) \\
\end{array}$ & $\begin{array}{c}-4.070^{* *} \\
(1.11) \\
\end{array}$ \\
\hline$\beta_{H R P}+\beta_{H R P \times P e r s}$ & & $\begin{array}{c}-1.357^{* *} \\
(0.52) \\
\end{array}$ \\
\hline Unit means & yes & yes \\
\hline Calendar time means & yes & yes \\
\hline \multicolumn{3}{|c|}{$\begin{array}{l}+\mathrm{p}<0.10 ;^{*} \mathrm{p}<0.05 ;{ }^{* *} \mathrm{p}<0.01 \text {. Dependent variable is } \\
\text { democratic transition. Probit with clustered standard er- } \\
\text { rors in parentheses. Unit- and year-means for all explana- } \\
\text { tory variables (and the dependent variable), and dura- } \\
\text { tion time polynomials ( } 3 \text { ) included in all models but not } \\
\text { reported. } 174 \text { regimes in } 108 \text { countries from } 1977-2006 \text {. } \\
\mathrm{N} \times \mathrm{T}=2304 \text {. }\end{array}$} \\
\hline
\end{tabular}


Table A-2: No unit fixed effects

\begin{tabular}{|c|c|c|}
\hline & Probit & RE Probit \\
\hline & $(1)$ & $(2)$ \\
\hline HRP & $\begin{array}{c}0.589^{*} \\
(0.29)\end{array}$ & $\begin{array}{c}0.489+ \\
(0.28)\end{array}$ \\
\hline HRP $\times$ Pers & $\begin{array}{c}-1.283^{* *} \\
(0.46)\end{array}$ & $\begin{array}{c}-1.091^{*} \\
(0.45)\end{array}$ \\
\hline Personalist & $\begin{array}{r}-0.117 \\
(0.17)\end{array}$ & $\begin{array}{r}-0.107 \\
(0.17)\end{array}$ \\
\hline Nbr democratic transitions & $\begin{array}{l}0.122 \\
(0.13)\end{array}$ & $\begin{array}{l}0.079 \\
(0.11)\end{array}$ \\
\hline Nbr post-civil war transitions & $\begin{array}{c}-0.424^{* *} \\
(0.11)\end{array}$ & $\begin{array}{c}-0.401^{* *} \\
(0.10)\end{array}$ \\
\hline Prior democracy & $\begin{array}{c}0.715^{* *} \\
(0.15)\end{array}$ & $\begin{array}{c}0.687^{* *} \\
(0.15)\end{array}$ \\
\hline Constant & $\begin{array}{c}-5.917^{* *} \\
(0.19) \\
\end{array}$ & $\begin{array}{c}-2.199^{* *} \\
(0.24) \\
\end{array}$ \\
\hline$\beta_{H R P}+\beta_{H R P \times P e r s}$ & $\begin{array}{c}-0.694+ \\
(0.41) \\
\end{array}$ & $\begin{array}{c}-0.602+ \\
(0.36) \\
\end{array}$ \\
\hline $\begin{array}{l}\text { Country RE } \\
\text { Calendar time } \\
\end{array}$ & $\begin{array}{c}\text { no } \\
\text { year FE }\end{array}$ & $\begin{array}{c}\text { yes } \\
\text { period FE }\end{array}$ \\
\hline Observations & 2118 & 2304 \\
\hline \multicolumn{3}{|c|}{$\begin{array}{l}+\mathrm{p}<0.10 ;^{*} \mathrm{p}<0.05 ;{ }^{* *} \mathrm{p}<0.01 \text {. Clustered standard errors } \\
\text { in parentheses. Duration time polynomials }(3) \text { in all models } \\
\text { but not reported. Year FE are calendar year dummies; } \\
\text { period FE are dummies for } 5 \text {-year periods. }\end{array}$} \\
\hline
\end{tabular}

The models in this table drop unit means or fixed-effects. The first column reports a standard probit model with year fixed-effects; the second reports a random effects probit with controls for five-year periods because the estimation does not converge with random effects and year fixed-effects. Both results are similar to those reported in the main text. 
Table A-3: Leader exits

\begin{tabular}{|c|c|c|}
\hline & LPM & $\begin{array}{c}\text { Conditional } \\
\text { Logit }\end{array}$ \\
\hline & (1) & $(2)$ \\
\hline HRP & $\begin{array}{c}0.103^{*} \\
(0.05)\end{array}$ & $\begin{array}{c}1.318^{*} \\
(0.66)\end{array}$ \\
\hline HRP $\times$ Pers & $\begin{array}{c}-0.238^{* *} \\
(0.07)\end{array}$ & $\begin{array}{c}-3.631^{* *} \\
(1.13)\end{array}$ \\
\hline Personalist & $\begin{array}{r}-0.060 \\
(0.05)\end{array}$ & $\begin{array}{l}-0.677 \\
(0.46)\end{array}$ \\
\hline Nbr democratic transitions & $\begin{array}{l}0.022 \\
(0.01)\end{array}$ & $\begin{array}{c}0.332+ \\
(0.19)\end{array}$ \\
\hline Nbr post-civil war transitions & $\begin{array}{c}-0.027+ \\
(0.01)\end{array}$ & $\begin{array}{c}-0.466^{*} \\
(0.23)\end{array}$ \\
\hline Prior democracy & $\begin{array}{l}0.042 \\
(0.05)\end{array}$ & $\begin{array}{l}0.115 \\
(0.46)\end{array}$ \\
\hline Log GDP per capita & $\begin{array}{l}-0.020 \\
(0.03)\end{array}$ & $\begin{array}{l}-0.350 \\
(0.54)\end{array}$ \\
\hline Log popuation & $\begin{array}{c}-0.212^{* *} \\
(0.07)\end{array}$ & $\begin{array}{c}-3.735^{* *} \\
(1.25)\end{array}$ \\
\hline Civil war & $\begin{array}{c}0.037^{*} \\
(0.02)\end{array}$ & $\begin{array}{l}0.450^{*} \\
(0.19)\end{array}$ \\
\hline Judicial independence & $\begin{array}{c}0.725^{* *} \\
(0.16)\end{array}$ & $\begin{array}{c}9.340^{* *} \\
(2.02)\end{array}$ \\
\hline$\beta_{H R P}+\beta_{H R P \times P e r s}$ & $\begin{array}{c}-0.135^{* *} \\
(0.05) \\
\end{array}$ & $\begin{array}{c}-2.312^{*} \\
(1.02) \\
\end{array}$ \\
\hline $\begin{array}{l}\text { Country FE } \\
\text { Year FE }\end{array}$ & $\begin{array}{l}\text { yes } \\
\text { yes }\end{array}$ & yes \\
\hline Observations & 2180 & 1582 \\
\hline \multicolumn{3}{|c|}{$\begin{array}{l}+\mathrm{p}<0.10 ;^{*} \mathrm{p}<0.05 ;^{* *} \mathrm{p}<0.01 \text {. Clustered standard errors } \\
\text { in parentheses. Duration time polynomials }(3) \text { or duration } \\
\text { dummies included in all models but not reported. Natural } \\
\text { death and term limited exits are treated as right-censored. }\end{array}$} \\
\hline
\end{tabular}


Table A-4: Non-violent regime transitions

\begin{tabular}{|c|c|c|}
\hline & LPM & $\begin{array}{l}\text { Conditiona } \\
\text { Logit }\end{array}$ \\
\hline & $(1)$ & $(2)$ \\
\hline HRP & $\begin{array}{c}0.082+ \\
(0.04)\end{array}$ & $\begin{array}{l}1.777 \\
(1.50)\end{array}$ \\
\hline HRP $\times$ Pers & $\begin{array}{c}-0.170^{* *} \\
(0.05)\end{array}$ & $\begin{array}{c}-4.854^{*} \\
(1.95)\end{array}$ \\
\hline Personalist & $\begin{array}{l}-0.043 \\
(0.04)\end{array}$ & $\begin{array}{c}-2.253^{*} \\
(1.02)\end{array}$ \\
\hline Nbr democratic transitions & $\begin{array}{l}0.006 \\
(0.01)\end{array}$ & $\begin{array}{l}0.255 \\
(0.46)\end{array}$ \\
\hline Nbr post-civil war transitions & $\begin{array}{r}-0.005 \\
(0.01)\end{array}$ & $\begin{array}{l}0.732 \\
(0.53)\end{array}$ \\
\hline Prior democracy & $\begin{array}{l}0.014 \\
(0.03)\end{array}$ & $\begin{array}{l}0.404 \\
(0.94)\end{array}$ \\
\hline Log GDP per capita & $\begin{array}{r}-0.021 \\
(0.02)\end{array}$ & $\begin{array}{l}1.717 \\
(1.43)\end{array}$ \\
\hline Log population & $\begin{array}{c}-0.125^{*} \\
(0.05)\end{array}$ & $\begin{array}{c}-30.470^{* *} \\
(8.96)\end{array}$ \\
\hline Civil war & $\begin{array}{c}0.018+ \\
(0.01)\end{array}$ & $\begin{array}{c}1.102^{*} \\
(0.53)\end{array}$ \\
\hline Judicial independence & $\begin{array}{c}0.446^{* *} \\
(0.12) \\
\end{array}$ & $\begin{array}{c}16.346^{* *} \\
(4.15) \\
\end{array}$ \\
\hline$\beta_{H R P}+\beta_{H R P \times P e r s}$ & $\begin{array}{c}-0.088^{* *} \\
(0.03)\end{array}$ & $\begin{array}{c}-3.077+ \\
(1.84)\end{array}$ \\
\hline $\begin{array}{l}\text { Country FE } \\
\text { Year FE }\end{array}$ & $\begin{array}{l}\text { yes } \\
\text { yes }\end{array}$ & yes \\
\hline Observations & 2294 & 950 \\
\hline
\end{tabular}

The logic of our argument should also apply to non-violent regime transitions. Examining democratic as well as non-violent transitions should increase our confidence in the findings because they measure slightly different conceptualizations of a transition where the incumbent relinquishes power. Unsurprisingly, there is a large overlap between the two variables. Roughly two-thirds of democratic transitions are non-violent and a similar share of non-violent transitions are also democratic. The democratic transition in Poland, for example, was not violent even though it entailed mass demonstrations against the Communist regime. In constrast, the Romanian transition to democracy was marked by both mass demonstrations and violence. In this case, the dictator and his wife were executed. Non-violent transitions in the data set from Geddes, Wright and Frantz 2014 are defined as the absence of deaths through the use of violent force during the regime transition event. The threat of violent force can be used during a transition event without resulting in deaths. For example, the ouster of the military junta in Haiti in 1994 by U.S. military forces entailed threats but no deaths from the use of violent force. 
Table A-5: Cheibub, Gandhi, and Vreeland (2010) democratic transitions

\begin{tabular}{|c|c|c|}
\hline & LPM & $\begin{array}{c}\text { Conditional } \\
\text { Logit } \\
\end{array}$ \\
\hline & $(1)$ & $(2)$ \\
\hline HRP & $\begin{array}{l}0.006 \\
(0.02)\end{array}$ & $\begin{array}{l}1.059 \\
(1.93)\end{array}$ \\
\hline HRP $\times$ Pers & $\begin{array}{c}-0.056+ \\
(0.03)\end{array}$ & $\begin{array}{c}-8.617^{*} \\
(3.52)\end{array}$ \\
\hline Personalist & $\begin{array}{c}-0.005 \\
(0.02)\end{array}$ & $\begin{array}{c}-1.874 \\
(2.93)\end{array}$ \\
\hline Nbr democratic transitions & $\begin{array}{c}0.013+ \\
(0.01)\end{array}$ & $\begin{array}{l}0.379 \\
(0.47)\end{array}$ \\
\hline Nbr post-civil war transitions & $\begin{array}{c}-0.014^{*} \\
(0.01)\end{array}$ & $\begin{array}{c}-1.303 \\
(1.00)\end{array}$ \\
\hline Prior dem & $\begin{array}{l}-0.025 \\
(0.02)\end{array}$ & $\begin{array}{l}0.517 \\
(1.76)\end{array}$ \\
\hline Log GDP per capita & $\begin{array}{c}-0.005 \\
(0.01)\end{array}$ & $\begin{array}{c}-5.285 \\
(3.41)\end{array}$ \\
\hline Log population & $\begin{array}{c}-0.076^{*} \\
(0.03)\end{array}$ & $\begin{array}{l}4.024 \\
(6.16)\end{array}$ \\
\hline Civil war & $\begin{array}{c}0.014+ \\
(0.01)\end{array}$ & $\begin{array}{l}0.496 \\
(0.79)\end{array}$ \\
\hline Judicial independence & $\begin{array}{c}0.212^{* *} \\
(0.07)\end{array}$ & $\begin{array}{c}39.217^{* *} \\
(8.22)\end{array}$ \\
\hline$\beta_{H R P}+\beta_{H R P \times P e r s}$ & $\begin{array}{c}-0.0497^{*} \\
(0.03)\end{array}$ & $\begin{array}{c}-7.558^{*} \\
(2.99) \\
\end{array}$ \\
\hline Country FE & yes & \\
\hline Year FE & yes & no \\
\hline Period FE & no & yes \\
\hline Observations & 2205 & 528 \\
\hline
\end{tabular}


Table A-6: Alternative time-trend specifications

\begin{tabular}{|c|c|c|c|c|}
\hline \multirow[t]{3}{*}{ Time trend } & \multicolumn{2}{|c|}{ Region-specific } & \multicolumn{2}{|c|}{ Global HRP trend } \\
\hline & LPM & $\begin{array}{l}\text { Conditional } \\
\text { Logit }\end{array}$ & LPM & $\begin{array}{c}\text { Conditional } \\
\text { Logit }\end{array}$ \\
\hline & $(1)$ & $(2)$ & $(3)$ & $(4)$ \\
\hline HRP & $\begin{array}{r}-0.012 \\
(0.04)\end{array}$ & $\begin{array}{l}0.102 \\
(1.27)\end{array}$ & $\begin{array}{l}0.058 \\
(0.04)\end{array}$ & $\begin{array}{l}1.064 \\
(1.08)\end{array}$ \\
\hline HRP $\times$ Pers & $\begin{array}{c}-0.125^{*} \\
(0.05)\end{array}$ & $\begin{array}{c}-10.874^{* *} \\
(3.75)\end{array}$ & $\begin{array}{c}-0.110^{*} \\
(0.05)\end{array}$ & $\begin{array}{c}-4.087^{*} \\
(1.79)\end{array}$ \\
\hline Personalist & $\begin{array}{c}-0.056^{*} \\
(0.03)\end{array}$ & $\begin{array}{c}-4.545^{* *} \\
(1.37)\end{array}$ & $\begin{array}{l}-0.041 \\
(0.03)\end{array}$ & $\begin{array}{c}-3.234^{* *} \\
(0.97)\end{array}$ \\
\hline Nbr democratic transitions & $\begin{array}{c}0.018^{*} \\
(0.01)\end{array}$ & $\begin{array}{c}0.847^{*} \\
(0.38)\end{array}$ & $\begin{array}{c}0.020^{* *} \\
(0.01)\end{array}$ & $\begin{array}{c}0.960^{* *} \\
(0.32)\end{array}$ \\
\hline Nbr post-civil war transitions & $\begin{array}{c}-0.011+ \\
(0.01)\end{array}$ & $\begin{array}{l}0.040 \\
(0.59)\end{array}$ & $\begin{array}{c}-0.018^{* *} \\
(0.01)\end{array}$ & $\begin{array}{c}-0.843+ \\
(0.49)\end{array}$ \\
\hline Prior dem & $\begin{array}{r}-0.020 \\
(0.04) \\
\end{array}$ & $\begin{array}{r}-0.832 \\
(0.93) \\
\end{array}$ & $\begin{array}{l}0.001 \\
(0.04)\end{array}$ & $\begin{array}{c}-1.833^{*} \\
(0.91) \\
\end{array}$ \\
\hline$\beta_{H R P}+\beta_{H R P \times P e r s}$ & $\begin{array}{c}-0.137^{* *}+ \\
(0.04)\end{array}$ & $\begin{array}{c}-10.771^{* *} \\
(3.63)\end{array}$ & $\begin{array}{c}-0.053^{* *} \\
(0.03) \\
\end{array}$ & $\begin{array}{c}-3.023^{*} \\
(1.50) \\
\end{array}$ \\
\hline Country FE & yes & & yes & \\
\hline Region time trend & yes & yes & no & no \\
\hline Global HRP trend & no & no & yes & yes \\
\hline Observations & 2304 & 861 & 2304 & 861 \\
\hline
\end{tabular}


Table A-7: Alternative HRP lags

\begin{tabular}{|c|c|c|c|c|}
\hline & \multicolumn{2}{|c|}{ 2-year lag } & \multicolumn{2}{|c|}{ 4-year lag } \\
\hline & LPM & $\begin{array}{l}\text { Conditional } \\
\text { Logit }\end{array}$ & LPM & $\begin{array}{l}\text { Conditional } \\
\text { Logit }\end{array}$ \\
\hline & $(1)$ & $(2)$ & $(3)$ & $(4)$ \\
\hline HRP & $\begin{array}{l}0.051 \\
(0.05)\end{array}$ & $\begin{array}{l}0.523 \\
(1.50)\end{array}$ & $\begin{array}{l}0.041 \\
(0.04)\end{array}$ & $\begin{array}{l}0.648 \\
(1.48)\end{array}$ \\
\hline HRP $\times$ Pers & $\begin{array}{c}-0.125^{*} \\
(0.06)\end{array}$ & $\begin{array}{c}-7.492^{*} \\
(3.17)\end{array}$ & $\begin{array}{c}-0.095^{*} \\
(0.04)\end{array}$ & $\begin{array}{c}-5.942^{*} \\
(2.49)\end{array}$ \\
\hline Personalist & $\begin{array}{l}-0.039 \\
(0.03)\end{array}$ & $\begin{array}{c}-3.628^{*} \\
(1.44)\end{array}$ & $\begin{array}{l}-0.037 \\
(0.03)\end{array}$ & $\begin{array}{c}-3.078^{*} \\
(1.51)\end{array}$ \\
\hline Nbr democratic transitions & $\begin{array}{l}0.009 \\
(0.01)\end{array}$ & $\begin{array}{l}0.766 \\
(0.49)\end{array}$ & $\begin{array}{l}0.009 \\
(0.01)\end{array}$ & $\begin{array}{l}0.738 \\
(0.51)\end{array}$ \\
\hline Nbr post-civil war transitions & $\begin{array}{r}-0.006 \\
(0.01)\end{array}$ & $\begin{array}{l}1.453^{*} \\
(0.73)\end{array}$ & $\begin{array}{r}-0.006 \\
(0.01)\end{array}$ & $\begin{array}{c}1.381+ \\
(0.72)\end{array}$ \\
\hline Prior demcoracy & $\begin{array}{r}-0.001 \\
(0.03)\end{array}$ & $\begin{array}{l}-1.254 \\
(1.12)\end{array}$ & $\begin{array}{r}-0.000 \\
(0.03)\end{array}$ & $\begin{array}{l}-1.294 \\
(1.14)\end{array}$ \\
\hline Log GDP per capita & $\begin{array}{r}-0.016 \\
(0.02)\end{array}$ & $\begin{array}{l}-2.134 \\
(2.08)\end{array}$ & $\begin{array}{l}-0.016 \\
(0.02)\end{array}$ & $\begin{array}{l}-2.132 \\
(2.07)\end{array}$ \\
\hline Log population & $\begin{array}{c}-0.136^{* *} \\
(0.05)\end{array}$ & $\begin{array}{c}-27.301^{* *} \\
(9.48)\end{array}$ & $\begin{array}{c}-0.135^{* *} \\
(0.05)\end{array}$ & $\begin{array}{c}-27.363^{* *} \\
(9.64)\end{array}$ \\
\hline Civil war & $\begin{array}{l}0.004 \\
(0.01)\end{array}$ & $\begin{array}{c}0.806 \\
(0.66)\end{array}$ & $\begin{array}{l}0.004 \\
(0.01)\end{array}$ & $\begin{array}{l}0.805 \\
(0.65)\end{array}$ \\
\hline Judicial independence & $\begin{array}{c}0.373^{* *} \\
(0.11)\end{array}$ & $\begin{array}{c}20.734^{* *} \\
(6.40) \\
\end{array}$ & $\begin{array}{c}0.372^{* *} \\
(0.11) \\
\end{array}$ & $\begin{array}{c}21.921^{* *} \\
(6.59) \\
\end{array}$ \\
\hline$\beta_{H R P}+\beta_{H R P \times P e r s}$ & $\begin{array}{c}-0.0740+ \\
(0.04) \\
\end{array}$ & $\begin{array}{c}-6.968^{*} \\
(2.86)\end{array}$ & $\begin{array}{c}-0.055+ \\
(0.03)\end{array}$ & $\begin{array}{c}-5.294^{*} \\
(2.17)\end{array}$ \\
\hline $\begin{array}{l}\text { Country FE } \\
\text { Year FE }\end{array}$ & $\begin{array}{l}\text { yes } \\
\text { yes }\end{array}$ & yes & $\begin{array}{l}\text { yes } \\
\text { yes }\end{array}$ & yes \\
\hline Observations & 2294 & 845 & 2294 & 845 \\
\hline
\end{tabular}


Table A-8: Religious neighbors

\begin{tabular}{|c|c|c|}
\hline & LPM & $\begin{array}{c}\text { Conditional } \\
\text { Logit }\end{array}$ \\
\hline & $(1)$ & $(2)$ \\
\hline HRP & $\begin{array}{c}0.173^{*} \\
(0.07)\end{array}$ & $\begin{array}{l}1.207 \\
(1.92)\end{array}$ \\
\hline HRP $\times$ Pers & $\begin{array}{c}-0.196^{*} \\
(0.08)\end{array}$ & $\begin{array}{c}-6.031^{* *} \\
(2.18)\end{array}$ \\
\hline Personalist & $\begin{array}{c}-0.033 \\
(0.05)\end{array}$ & $\begin{array}{l}0.160 \\
(1.94)\end{array}$ \\
\hline Nbr democratic transitions & $\begin{array}{l}0.008 \\
(0.01)\end{array}$ & $\begin{array}{l}0.575 \\
(0.58)\end{array}$ \\
\hline Nbr post-civil war transitions & $\begin{array}{r}-0.008 \\
(0.01)\end{array}$ & $\begin{array}{l}0.042 \\
(0.81)\end{array}$ \\
\hline Prior democracy & $\begin{array}{l}-0.022 \\
(0.04)\end{array}$ & $\begin{array}{c}-6.808^{* *} \\
(2.39)\end{array}$ \\
\hline Log GDP per capita & $\begin{array}{l}-0.019 \\
(0.02)\end{array}$ & $\begin{array}{c}-6.321^{*} \\
(2.88)\end{array}$ \\
\hline Log population & $\begin{array}{c}-0.136^{* *} \\
(0.04)\end{array}$ & $\begin{array}{l}-20.190 \\
(13.00)\end{array}$ \\
\hline Civil war & $\begin{array}{l}0.007 \\
(0.01)\end{array}$ & $\begin{array}{l}0.109 \\
(0.75)\end{array}$ \\
\hline Judicial independence & $\begin{array}{c}0.380^{* *} \\
(0.13) \\
\end{array}$ & $\begin{array}{c}33.875^{* *} \\
(10.67) \\
\end{array}$ \\
\hline$\beta_{H R P}+\beta_{H R P \times P e r s}$ & $\begin{array}{r}-0.022 \\
(0.04)\end{array}$ & $\begin{array}{c}-4.824^{* *} \\
(1.71)\end{array}$ \\
\hline $\begin{array}{l}\text { Country FE } \\
\text { Year FE }\end{array}$ & $\begin{array}{l}\text { yes } \\
\text { yes }\end{array}$ & yes \\
\hline Observations & 2018 & 715 \\
\hline
\end{tabular}

$+\mathrm{p}<0.10 ;^{*} \mathrm{p}<0.05 ;{ }^{* *} \mathrm{p}<0.01$. Clustered standard errors in parentheses. Duration time polynomials (3) or duration dummies included in all models but not reported. 


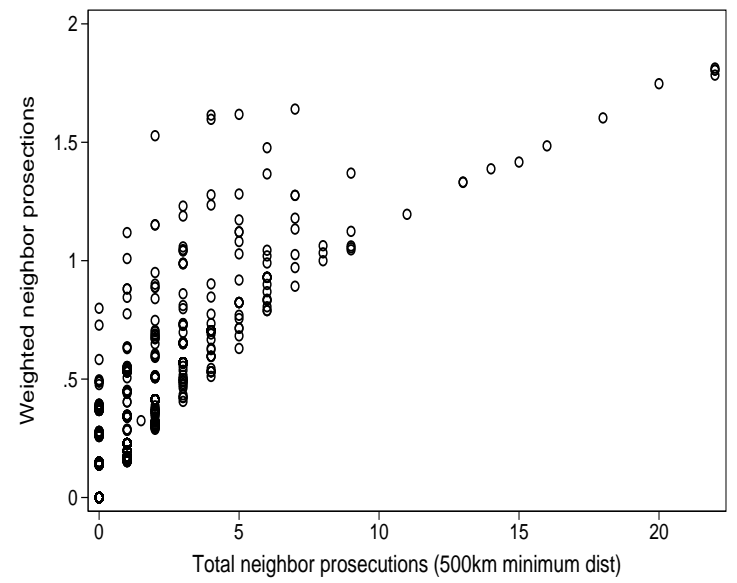

Figure A-1: Weighted neighbor prosecutions index. The vertical axis shows the values for the minimum distance-weighted measure of neighbor prosecutions. The horizontal axis shows the values for the number of neighbor country prosecutions using a $500 \mathrm{~km}$ minimum distance threshold, which is the threshold employed in Gleditsch and Ward (2006) to define 'neighboring country.' 


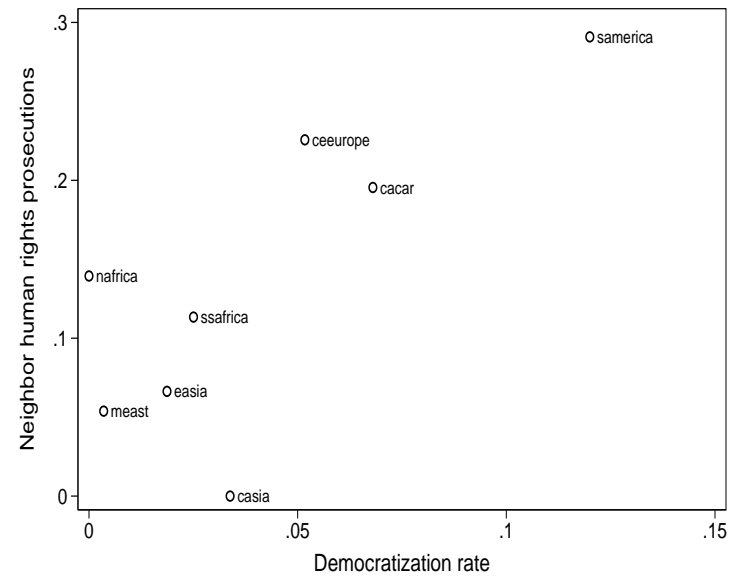

Figure A-2: Regional neighbor prosecutions and democratization. Horizontal axis is the democratization rate for dictatorships in a particular geographic region. Vertical axis is the mean level of the neighoring country prosecutions index, by geographic region. 
Conditional logit simulation

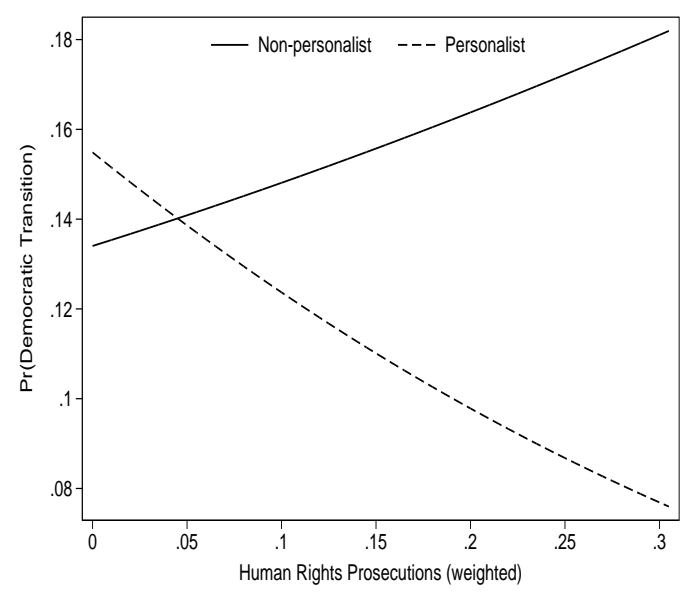

Figure A-3: Conditional logit simulation. Simulated predicted risk of democratic transition, from model estimates reported in column (2) of Table 1, except time period dummies were used instead of year fixed effects. All explanatory variables set at mean or median. The horizontal axis depicts a range of values for the weighted HRP variable, up to roughly one standard deviation above the mean. The absolute value of the estimates should not be interpreted literally because the conditional logit sample drops countries that do not democratize and therefore biases the baseline probability of democratic transition upwards. 


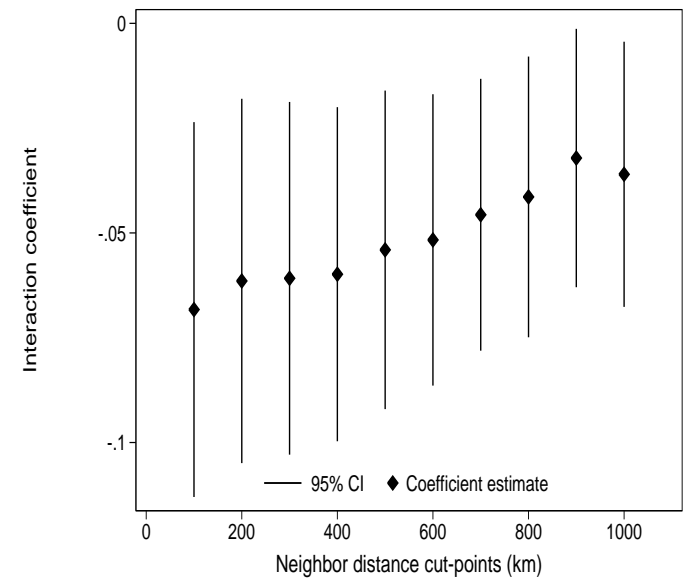

Figure A-4: Interaction term, by distance cut points. Estimated interaction coefficients $(H R P \times$ Personal $)$ for the linear probability model in Table 1, column 5 . Instead of using the weighted distance measure, these models use a binary cut-point for which all neighbor prosecutions below various cut-points (displayed on horizontal axis) are counted and weighted equally. Minimum distance data from Gleditsch and Ward (2006); they employ a $500 \mathrm{~km}$ minimum distance threshold. 